\title{
Celebrating the Dead in Ayyūbid Egypt: A Survey into Meaning and Architectural Manifestation
}

\author{
Essam S. Ayyad \\ Faculty of Tourism, Suez Canal University
}

\begin{abstract}
Although the commemoration of the dead is a universal and a long-standing tradition, early Islam is widely known to have resisted it. After a relatively long period of observing prevention, such an antique practice nonetheless found its way to Islamic culture. It is true that celebrating the dead was introduced to the realm of Islam before the Shī' $\overline{1}$ Fatimids founded their caliphate in Tunisia in 296/909, but it was under them that this praxis reached the zenith. The Fatimids were succeeded by the Ayyūbids who, in spite of being a zealous Sunnī dynasty, upheld the tradition of celebrating the departed notables, particularly the pious ones (awliy $\left.\bar{a}^{\prime}\right)$. The aim in this paper is to explore how such a practice, which is widely deemed unorthodox in the eye of Sunnī Islam, was maintained in Egypt under the Ayyūbids (567/1172648/1250). In particular, the paper attempts to give an insight into: (i) the types of the dead dignitaries that were celebrated under the Ayyūbids; (ii) the features that must be existing in their biographies so as to be canonized-in the Islamic sense; (iii) the architectural expressions that were employed to celebrate their memory; (iv) and the meaning of such a procedure.
\end{abstract}

Keywords: The dead, Ayyūbid, mausolea, Egypt, funerary, pious, celebration, public.

\section{Introduction}

Sunnī Islam developed clearly judgemental conventions against funerary architecture. Such a stance is based on quite a big number of prophetic traditions. All accentuate that a grave must not be underscored by any given means, including: tajṣiș, 'treatment with lime-mortar', tatyīn, 'covering with clay' and kitāba, 'inscription'. ${ }^{1}$ First and foremost, mosques must not be built on a tomb or at a graveyard. ${ }^{2}$ Islam's condemnation of putting up structures, particularly religious ones, over sepulchres is typically assumed to mirror a static opposition to idolatry and apotheosis: both are believed to have developed from exalting the graves of the departed ancestors, principally the pious amongst them. ${ }^{3}$ This situation, as believed by a majority of Muslim scholars, represented a genuine menace to early Islam and an enormous contest for the Prophet and the early religious authorities who were concerned that the same would happen to the adherents of the new religion. This may explain the huge corpus of tradition in which the Prophet, followed by early șahābis and tabi $\bar{\imath} s$, expresses a conspicuous censure to any sort of celebrating the dead. ${ }^{4}$

Narrated 'A' isha: Umm Habība and Umm Salama [two of the Prophet's wives] mentioned a church they had seen in Abyssinia. In which there were pictures. They told the Prophet about it and he said: 'If any pious man dies amongst those people they would build a place of worship at his grave and make such pictures in it. Those will be the worst creatures in the sight of Allāh on the Day of Judgment.' 5

Such a tendency was strong enough to guarantee the prevention of erecting any funerary structures for at least several decades. This assumption is backed up by the absence of any reliable archaeological evidence for tombs or mausolea dating to the time of the Rāshidūn or the Umayyads. Some ascribe the lacking Umayyad funerary structures to the mutilation caused to them by the 'Abbāsids who wanted to wipe out the history of their political adversaries. According to this point of view, the Umayyads' tombs were obliterated, their graves were exhumed and their bones were buried in unknown places. ${ }^{6}$ It may be for this reason why the burial places of the majority of the 'Abbāsid caliphs were hidden. ${ }^{7}$ We are told, for instance, that a hundred graves were made for Abū Ja far al-Manșūr, lest his body should be desecrated if tracked down. This hypothesis, however, is still doubtful for it fails to explain why we could not find in the sources any reference to an Umayyad tomb, in case any once existed. The most acceptable theory is that the Umayyads did not fundamentally erect funerary domes.

In keeping with this line of thinking, Creswell states that the prohibition of building domes on graves was observed until the third/ninth century. The first caliph to let his burial place revealed was al-Muntașir (r. 861/247862/248), son of al-Mutawakkil (r. 847/232-861/247). A dome, known as Șulaybiyya, was built for him in Samarra in 248/862 by command of his Greek mother. ${ }^{8}$ Oleg Grabar, providing a useful chronological listing for the early Islamic mausolea, ${ }^{9}$ theorizes that the Qubbat al-Șulaybiyya was followed by that of Ismā '̄l al-Sāmanī in Bukhara (295/907). According to him, the tomb of imām 'Alī at Najaf was topped was a dome for the first time in 289/902. ${ }^{10}$ The reports on the comrades of the șahāāi 'Utba b. Usayd (whose epithet was Abū Bașīr) building a mosque on his grave in 6/627-8 is deemed by a majority of art historians as antedated. ${ }^{11}$ There are reports, however, that funerary domed structures were introduced to Islam in the late second/eighth century; that is even before the Sulaybiyya. We are told that when the mother of the vizier al-Faḍl b. Yahyā b. Barmak died, Hārūn al-Rashīd (r. 170/786-193/809) ordered that a dome should 
be built on her grave. It was later known as the Barmakid Dome. ${ }^{12}$ Further, al-Ma' mūn (r. 198/813-218/833) erected a dome over the tomb of al-Rashīd and that of 'Alī b. Mūsā al-Riḍa (d. 203/819). ${ }^{13}$

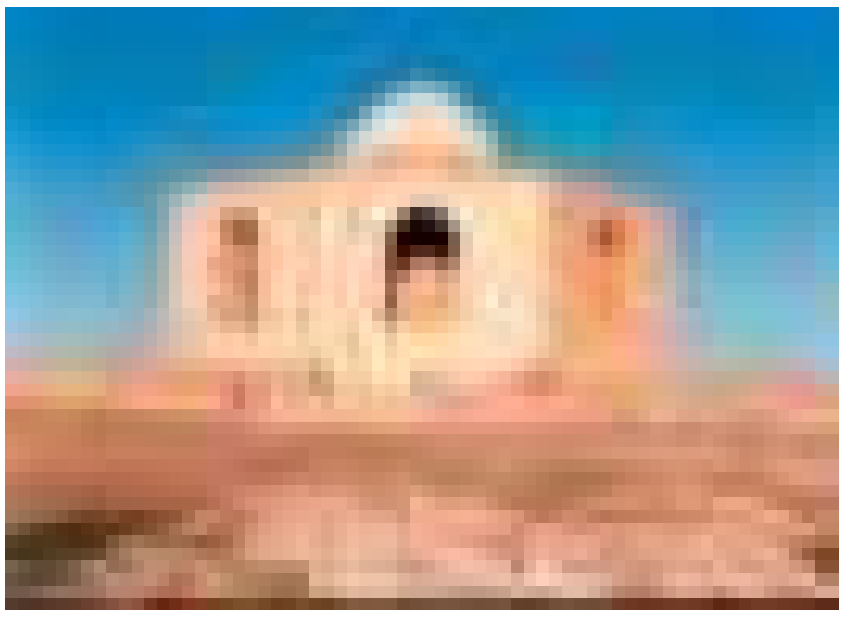

Pl. (1): Qubbat al-Șulaybiyya

(http://www.panoramio.com/photo/5307931)

In Islamic Egypt, funerary architecture is said to have been known even before the advent of the Fatimids. It began as an aristocratic observation. The mashhad of Āl Ṭabātabā (334/943) from the Ikhshidid period is widely believed to be the earliest example of a domed funerary structure in Islamic Egypt. ${ }^{14}$ According to some, such precedence goes to the seven domes (400/1010). ${ }^{15}$ We shall see below that even these are said to have been preceded by older examples.

In what follows, we will try to investigate the terminology and connotation related to funerary structures in Ayyūbid Egypt. The paper will then look into the places where the Muslim Egyptians usually buried their dead. It will also look into the nature of the observances that took place in such necropolises. This will be followed by an attempt to identify those whose tombs were celebrated in the same period of time. We will further explore the rationale behind such a selection. Also, there will be an inquiry into how the graves of those notables were architecturally accentuated. It should be noted, here, that this paper does not aim to consider the architectural evolution of the Ayyūbid mausolea in Egypt, for this has been copiously discussed by recent research. Rather, it will try to explore which forms prevailed and why. In this, the mausoleum of imam al-Shāfi 'i will be dealt with as a model.

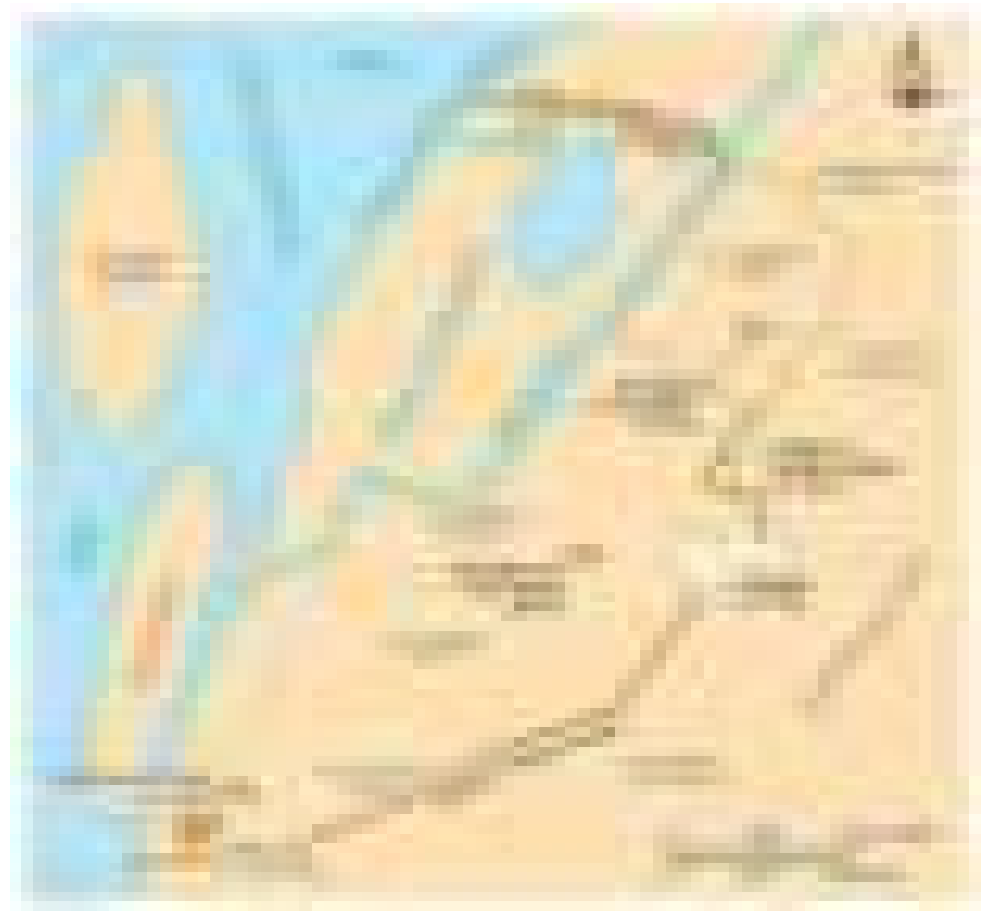

Fig. (1): Map of Ayyūbid Cairo (RichardYeomans, 2006) 
Terminology and usage

It seems that in the fourth/tenth century, the term mashhad was used to denote, in addition to purely funerary structures, the mosques beneath which the pious were allegedly buried. Both words, mashhad and masjid, were used interchangeably and both were conceived as blessed places. Al-Ḥasan b. Ibrāhīm al-Laythī, best known as Ibn Zulāq (d. 387/997), used the subheading: 'the blessed mosques and the great mashhads' to relate his reports on the mosques which were built on the graves of the notable șahābiss and tabi $\bar{\imath} s .{ }^{16}$ For Ibn Zulāq, such places were known for the likelihood that supplication at them is to be fulfilled. ${ }^{17}$ In this sense, mashhad is used to specify any place that is visited (literally witnessed) by the public, particularly in search for benediction and blessing.

Even before the advent of the Ayyūbids, there were generally two types of mashhads: real ones and cenotaphs. In medieval Islam the latter-usually referred to in the sources as mashähid al-ru'yā- proved to be a workable political device for the Fatimids. This, however, continued to be employed under the Sunni Ayyūbids. The custom was that the supreme religious authority in a certain place declared that he had dreamed of a sacred figure asking that a commemorative tomb should be dedicated to him or her in a particular place. Sometimes, such a sacred figure is 'canonized' by the Prophet himself through a dream or a vision. For example, al-Fakhr al-Fārisī (d. 622/1225), whose titles included: 'the greatest shaykh of Islam and the conqueror of heretics', is said to have seen the Prophet Muhammad in a dream asking him to build a mosque at the tomb of shaykh Abū al-Khayr al-Tīnātī. ${ }^{18}$ Also, the tomb of Shihāb al-Dīn al-'Umarī (d. 629/1232) is said to be marked out for him by the Prophet in a dream. ${ }^{19}$ Also, a tomb attributed to an anonymous repentant young man is said to be a place where supplications are prone to acceptation. It is said that one of the pious people, 'șalihiūn', had dreamed of the Prophet while praying and supplicating towards its front. ${ }^{20}$ Such reports, even if not verified, were enough for the laity to have belief in the privilege of such places. ${ }^{21}$

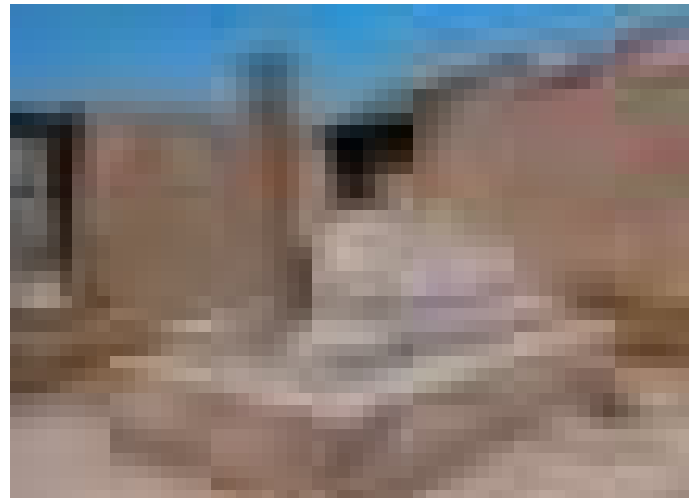

Pl. (2): Grave of Abū al-Khayr al-Tīnātī

(http://www.msobieh.com/akhtaa/viewtopic.php?f=17\&t=17480)

The most common expression used by medieval Muslim historians to connect such religious personages to the shrines dedicated to them in Egypt, a place which none of them is known to once visit, was: ' $r a$ 'awhum fi-l manam', or 'ru'u fi-l manām', 'they have been seen in dream'. ${ }^{22}$ Some of such pseudo-burial places were dedicated to the Prophet himself, such as the one in Qūș, Upper Egypt. Also in the same village a cenotaph was devoted to 'Alī b. Abī Ṭālib. ${ }^{23}$ In Mahalla, there were cenotaphs for Fāṭima, her husband 'Alī and son al-Husayn. Similar cenotaphs were found in Shata, Tanis, Tuna. ${ }^{24}$

The funerary structures of the polity, who for the most part lacked religious prestige, are usually referred to in the literature using terms like darīh and qubba, but not mashhad. The latter, it seems, had to be linked with frequent visits of those seeking blessing-perhaps intercession (see below). Linguistically, the term darị is so called on account of being dug in earth. According to Ibn Manzūur, 'darīḥ' is used when the crevice (where the dead is interred) is located in the middle of the grave; if it is made on one side of it, it is then called 'lahd'. Just like qabr, the term darih later developed to specify both the grave and the topping structure. ${ }^{25}$ Other Arabic synonyms include maqbara, madfan and maqām. The latter is commonly used-alongside mashhad - to exclusively denote the tombs belonging to the Muslim saints (i.e. ashrāf and șüfis, together referred to as awliyā' Allāh, 'patrons of God').

The graveyard, on the other hand, was commonly referred to as turba. It was further known as hüsh and zarbiyya. Examples of the former are the $h \bar{u} s h$ of al-Fāsī ${ }^{26}$ and that of al-Za farānīi ${ }^{27}$ An example of the latter is the zarbiyya, 'lit. pen', of Fakhr al-Dīn al-Fārisīi ${ }^{28}$ It encloses a number of other tombs for people died in the Ayyūbid period, such as al-Fāris̄̄’s emancipated slave shaykh Bilāl (d. 631/1234) and Karīm al-Dīn al-A 'jamī, the shaykh of the khanqā Sa '̄id al-Su 'adā'. ${ }^{29}$

\section{Where did the Muslim Egyptians bury their dead?}

According to al-Maqrīzī, in the beginning—since the Muslim conquest and the foundation of Fustāt — the Muslims of Egypt used to bury their dead near their dwellings in the eastern part of Mișr, i.e. in a place later known as al-Qarāfa al- 
Kubrā, 'the Great Necropolis'. ${ }^{30}$ Al-Qarāfa al-Șughrā, 'the Small Necropolis', however, was located at the foot of the Muqatțam Hill, ${ }^{31}$ which itself was regarded as a blessed gravesite. The Necropolis is given this nomination after a tribe called Banū Qarāfa b. Mughāfir. A man called 'Āmir, from this tribe, is said to have been the first Muslim to be buried there. ${ }^{32}$

Ibn Zulāq remarks that the Muqaț̣am was looked upon by the public as part of al-Ṭūr al-Muqaddas of Sinai. ${ }^{33}$ Some reports argue that such a place was prophesied by Prophet Jesus to be the boneyard of the Muslims. ${ }^{34}$ The hill was recognized as the gravesite of the pious people, and hence was widely known as ghirās al-janna, 'the seedling of Paradise'. ${ }^{35}$ It is reported of al-Hasan al-Bașrī to have said that it is from the Muqațam that the martyrs are to be led to God on the Day of Resurrection. ${ }^{36}$

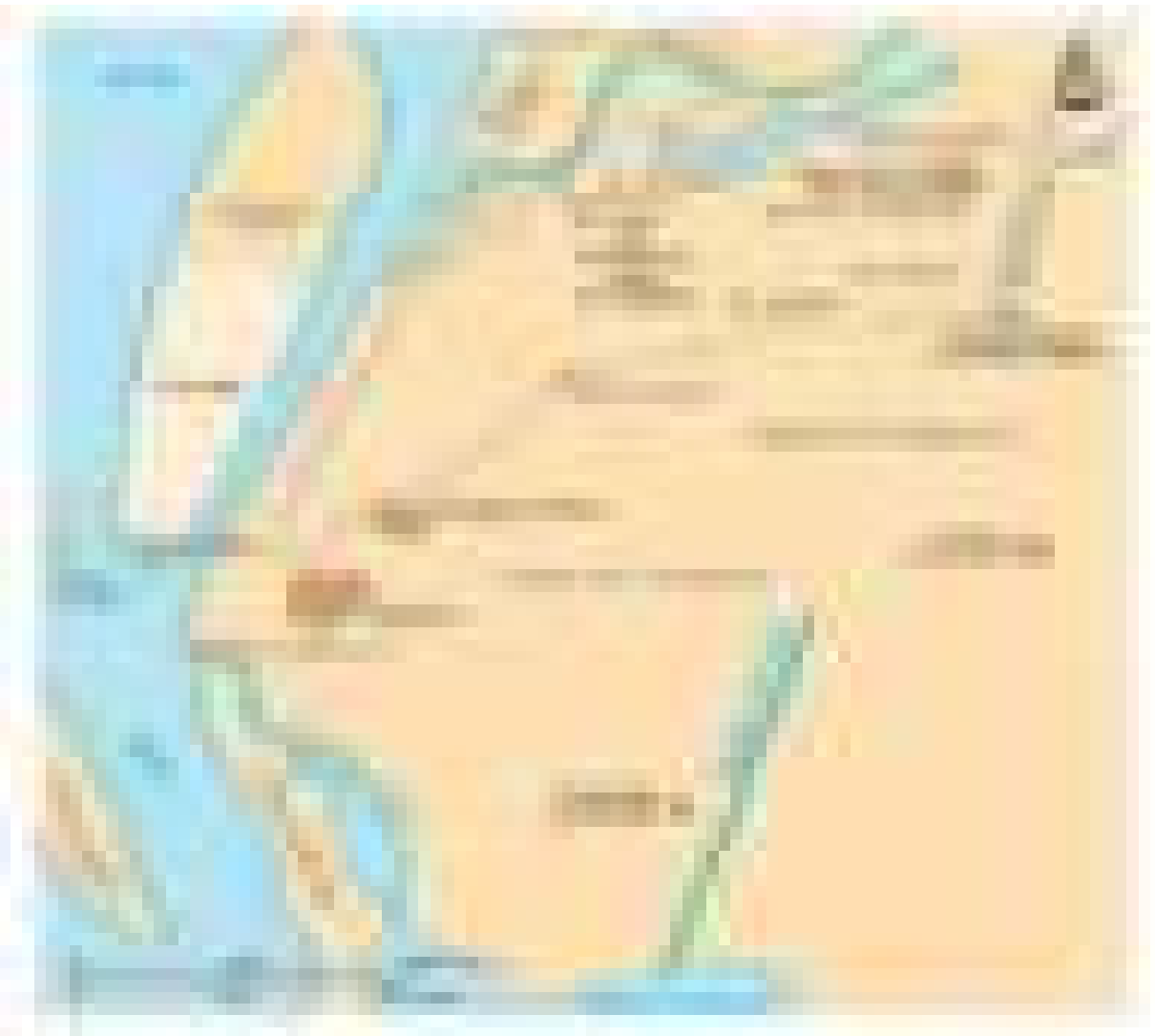

Fig (2): Location of the two main necropolises (Richard Yeomans, 2006)

The Qarāfa was not simply a gravesite, but witnessed a range of public events. A number of the $r u$ 'as $\bar{a}^{\prime}$, 'notables', are said to have accustomed to sleeping in al-Qarāfa chief mosque and to spending the summer nights conversing in its court. Stating that the presence of such notables attracted the plebs, al- Maqrīzi indicates that this was the case with the majority of the mosques and mashhads at the Qarāfa and the al-Muqatțam. The public were tempted to come by the varieties of sweet, meat and other items of food that were either brought to or made at these places. ${ }^{37}$

How the Qarāfa looked like in medieval Islam? Mūsā b. Muḥammad b. Sa ${ }^{1} \mathrm{~d},{ }^{38}$ who himself spent many nights in the Qarāfa of Fustạț, reported that the tombs were topped with carefully built structures, including the great, high and ornate dome of al-Shāfi $\overline{1}^{3} .{ }^{39}$ Ironically, the Qarāfa, which according to al-Maqrīzī looked like a white township, ${ }^{40}$ served as a recreational area for the people of medieval Mișr who gathered there in moony nights and were entertained even by singers. ${ }^{41}$

In spite of the many texts of interdiction (including hadīths, commentaries and treatises), the erection of tombs was not presumably deemed a taxing transgression by the contemporary Sunni scholars. It should be noted here that quite a big corpus of hadīth praised ziyāra and thus later commentaries established the etiquette related to it. ${ }^{42}$ Imām Abū Muhammad al-Qāsim al-Shāțibī (d. 590/1194), for example, who spent much of his life teaching hadīth at the madrasa Fādiliyya, was buried in the tomb of al-qāḍ̄ al-Fādil (d. 596/1200), the renowned wordsmith and vizier of Șalāh al-Dīn. ${ }^{43}$ Tombs were visited not only by the laity but also by the religious elite. The difference in motivation and behaviour of both teams may well explain why it is not religiously accepted for the former and accepted for the latter. The grave of al-Layth b. Sa'd (d. ca. 175/791), for instance, was visited by al-Shāfi' $1 \overline{1}$ who liked to pay tribute to the former's memory. ${ }^{44}$ 


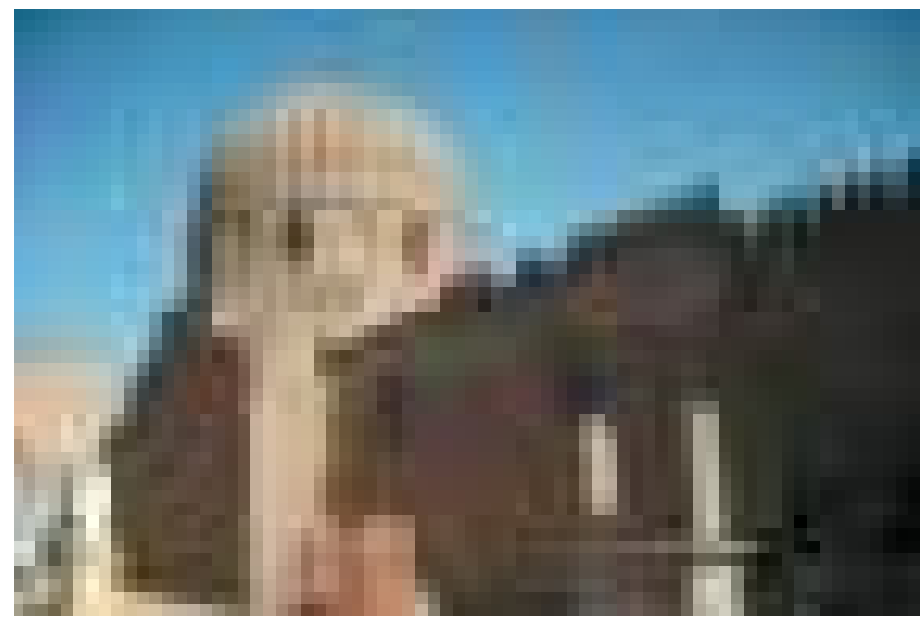

Pl. (3): Mashhad of al-Qāsim al-Shāṭibī

(http://www.msobieh.com/akhtaa/viewtopic.php?f=17\&t=14073)

Whatever the form such early tombs had taken, they were reportedly habitually frequented and celebrated by the Shī $\overline{1}$ crowds even before the advent of the Fatimids. Al-Maqrīzì expressly states-on the authority of an eyewitness, Ibn Zulāq - that a group of Shī' 1 wailers used to visit on the Day of 'Āshurā' the two mashahds of Sayyida Nafìsa and Umm Kulthūm (even under the Ikhshidids and Kāfūr). This usually caused some fierce friction between them and the Sunni citizens. According to al-Maqrīzì's account of Ibn Zulāq, such Shī'̄i mourners were particularly consolidated by al-Mu'izz's ascension to the Egyptian throne. Formerly, they were tamed by Kāfūr and his Sudanese allies. ${ }^{45}$

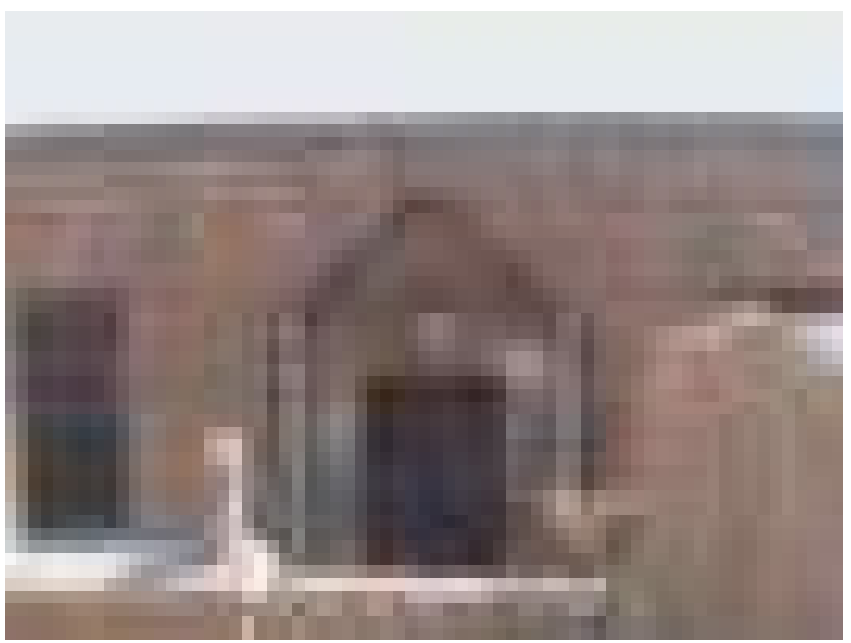

Pl. (4): Mashhad of Sayyida Umm Kulthūm

(http://www.msobieh.com/akhtaa/viewtopic.php?f=17\&t=13868)

Al-Maqrīzī tells us that al-Qarāfa was usually visited on Wednesdays before this was replaced with Thursday's nights (laylat al-Jumu 'a). ${ }^{46}$ According to him, the first to launch Wednesday's visit was a Shāfi' 'îte, Abū Muhammad 'Abd Allāh b. Rafi' (also known as 'Ābid) (d. 638/1241), who started his visit with the mashhad of Sayyida Nafīsa. ${ }^{47}$ However, the first to visit at Thursday's night was Abū al-Hasan 'Alī b. Jawshan (known as Ibn alJabbās) who gathered the people for a visit each Thursday's night. On occasion, Ibn al-Jabbās was accompanied with sultan al-Kāmil himself along with the most notable contemporary scholars. ${ }^{48}$

From the Ayyūbid period, we have examples for funerary monuments founded by those who themselves later lay within. For instance, the mausoleum of the 'Abbāsid Caliphs, which is architecturally analogous to that of Shajar alDurr, belongs to one Abū Nādila, an ambassador of a number of the 'Abbāsid Caliphs, who built this darịh for himself before he died in 640/1242. ${ }^{49}$ Likewise, Shajar al-Durr-possibly alerted by the assassination of her husband-built her own mausoleum just few years before her murder in 655/1257. ${ }^{50}$ Also, beneath the mosque of Zahrūn are the tombs of the Khawlāniyyūn whose names are inscribed on marble gravestones. The gravestone of the one who built the mosque relates his name and the fact that he built the tomb for himself in 35o/961 while at the age of forty five. ${ }^{51}$ 


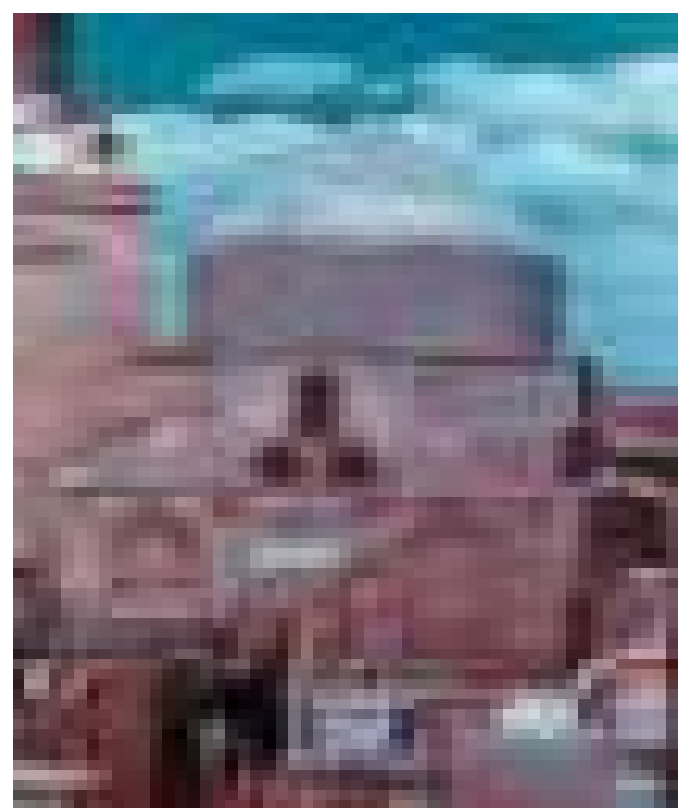

Pl. (5): Mausoleum of the 'Abbāsid Caliphs (Creswell's Archive)

There are also cases in Ayyūbid Egypt where the memorial was built by some of the dead's family. The mausoleum of al-Șāliḥ Najm al-Dīn Ayyūb (d. 568/1173), for example, was built for him by his widow Shajar alDurr. ${ }^{52}$ It was not until 648/1250 that his body was moved from his grave at Rawda to his, by then, newly erected dome adjoining his madrasa at al-Mu izz Ave. ${ }^{53}$

Sometimes, the will of someone spelled out his/her wish to be buried in a certain place, usually near to a departed righteous figure. The tomb of shaykh Abū 'Abd Allāh Muhammad al-Fiḍ̣̂̄ (d. 524/1130) was built near to that of the remarkable muhaddith Ibn Lahī'a (d. ca. 174/ 790). ${ }^{54}$ Also, imām Fakhr al-Dīn 'Alī b. al-Qafașī is said to have commended that he would love to be buried in the turba of shaykh Abū al-Faḍl b. al-Jawharī al-Wā' iz (d. 480/1087). ${ }^{55}$ Just like Ibn Lahī'a, Abū al-Faḍl had a splendid career; he was a strong proponent of Sunnism. ${ }^{56}$

Many of the celebrated tombs were known for the public to be places where invocation is likely to be accepted. Based on dreams, some of those who are buried beneath called for visits and promised rewards. ${ }^{57}$ It is usual to read in the literature about dreams related to the cemetery: some telling the high status of the entombed, others telling the woes which they suffer, others teaching some of the morals related to visit of the necropolis. In many cases, these messages were allegedly conveyed by the Prophet himself. ${ }^{58}$

\section{Whose tombs were celebrated in Ayyūbid Egypt and why?}

Departing from the previous point, in this section we will try to investigate those personages whose tombs were likely to be commended by the populace in Ayyūbid Egypt. Under the Ayyūbids, mausolean structures were generally dedicated to different types of personages: șahāāis, ashrāf (descendants from 'Alī and Fātịma), faqīhs, ulema, șūfīs,

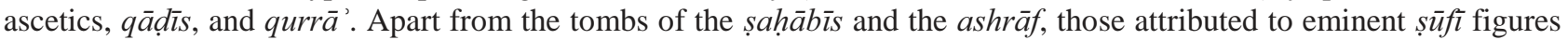
were typically the most celebrated. This may well be attributed to the fact that the mystic life and attributes of the șufis were in a better accordance with the 'veneration of saints'. In addition, the tombs of those who passed long ago were usually more likely to be venerated than the tombs of those who passed at a late date. Usually, the long age gives the necessary context for the spiritual significance of the departed to form and materialize. It would also give enough space for anecdotes to be spanned around the blessings of their tombs. ${ }^{59}$

\section{Pre-Islamic figures}

Like many peoples of the time, the Muslims of Ayyūbid Egypt were obsessed with the commemoration of the eminent dead. Many of the popular tombs were already celebrated long time before the Ayyūbids. This was applied not only to Islamic dead notables, but also to pre-Islamic ones-Prophets and other important historical figures are included. It was believed, as reported by al-Harawī, that the tombs of Prophet Jacob, his sons Rubin and Yehuda, as well as those of Zuleika, Prophets Moses and Elisha were all located in Cairo. ${ }^{60}$ Public attention was also paid to the place where Moses' cow is said to have been slaughtered ${ }^{61}$ Further, a mashahd was dedicated to the place where the crest of the $s \bar{a}^{\text {c }}$ of Potiphar, ${ }^{62}$ known in Islam as al- Azizz, is said to be located. ${ }^{63}$ Other mashhads were dedicated to places related to the biography of Joseph, Moses, Jesus, Jacob, and Abraham. ${ }^{64}$ Of these, Ibn Zulāq acknowledged Moses' blessed valley and the palm tree which Mary was commanded to shake so as to feed herself. ${ }^{65}$ 
The grave of Galen of Pergamon is also said to be located somewhere in Pelusium. ${ }^{66}$ A certain mosque was believed by the public to be attributed to Shem, Noah's eldest son, who according to them was buried therein. AlMaqrīzī argues that it was originally a synagogue known as Shem, or Sam b. Noah. Al-Sakhāwī excludes such an assumption and attributes the mosque to Muhammad b. 'Umar b. Jāmi' al-Bannā' (d. 591/1195) who was buried in the Qarāfa. ${ }^{67}$

Among these and other tombs and memorials, public appraisal was mainly focused upon those related to the righteous figures in the eye of Islam; while the graves of the Prophets were visited in search for blessings, those attributed to historical figures were mainly visited out of curiosity.

\section{Companions of the Prophet}

The Ayyūbids took certain care of the șaḥābīs' graves. The dynasty's founder, Șalāh al-Dīn, is said to have erected a dome for the two graves of 'Amr b. 'Āṣ and Abū Bașra al-Ghifārī; both included in the mashhad of 'Uqba b. 'Āmir alJahnī (d. 58/678), ${ }^{68}$ which also contains his gabled shrine. ${ }^{69}$

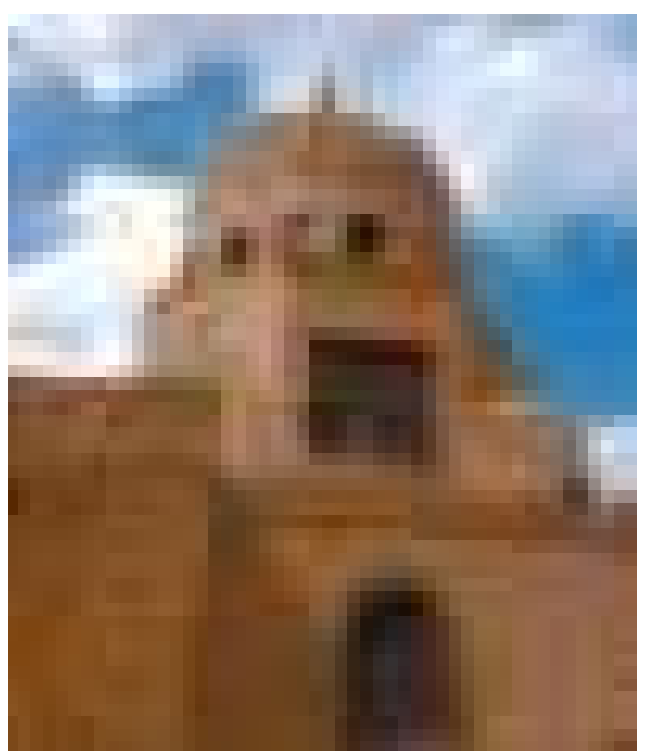

Pl. (6): Darīh of 'Uqba b. 'Āmir al-Jahnī

(http://www.msobieh.com/akhtaa/viewtopic.php?f=17\&t=16445)

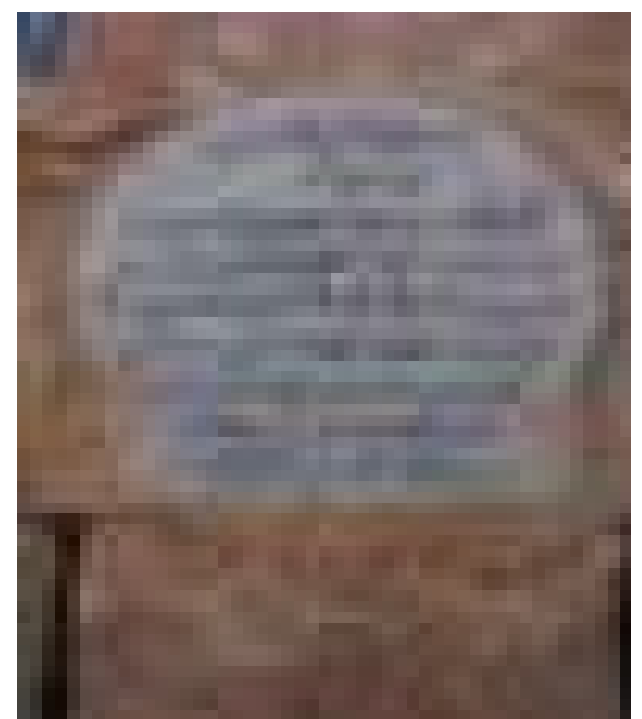

Pl. (7): Tombstone of 'Uqba b. 'Āmir al-Jahnī, 'Amr b. 'Āṣ and Abū Baṣra al-Ghifārī (http://www.msobieh.com/akhtaa/viewtopic.php?f=17\&t=10243) 
Essam S. Ayyad

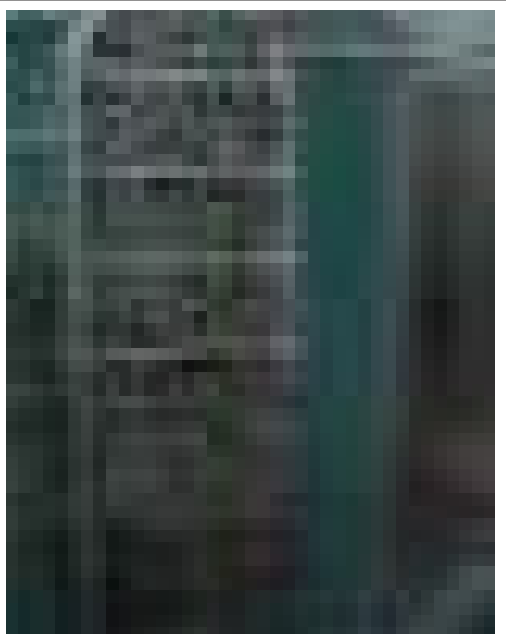

Pl.(8): Grave of 'Uqba b. 'Āmir al-Jahnī

(http://www.msobieh.com/akhtaa/viewtopic.php?f=17\&t=10243)

$\overline{A l}$ al-Bayt

A greater and a more established homage was bestowed upon the tombs of the members of the $\bar{A} l$ al-Bayt, whose memory was already venerated by the Egyptians long time before the Fatimids. For example, al-Maqrīzī, quoting alKindī's Al-Umarā', relates that the head of Zayd b. 'Alī was brought to Egypt in 122/740 by a certain Abū al-Hakam b. $A b \bar{i}$ al-Abyad who placed it in the mosque and preached the people who amassed for the event. ${ }^{70}$ Moreover, the first to build a memorial structure on the grave of Sayyida Nafĩsa was not the Fatimids, but 'Ubayd Allāh b. al-Sarī b. alHakam (r. 206-10/822-6). Her mausoleum was said to have been regularly visited by a great number of ulema and pious people who used to supplicate to God therein; one of those was imam al-Shāfi $\bar{i}^{71}{ }^{71}$

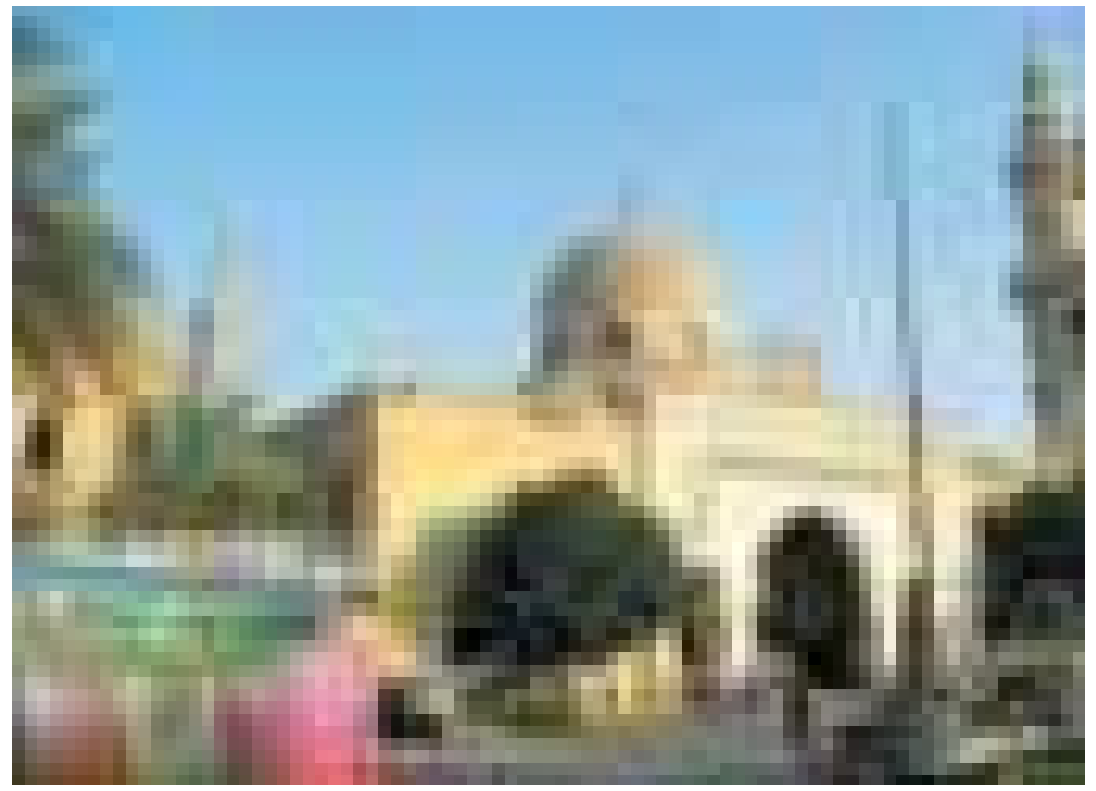

PI. (9): Mashhad of Sayyida Nafisa

(http://www.alchamel14.org/vb/showthread.php?t=37142\&page=2)

Such deference to the memory of the Âl al-Bayt did not necessarily require a Shî' $\overline{1}$ community. Indeed, the advent of the Fatimids in 358/969 does not seem to have guaranteed the Egyptian Sunnīs converting into Shiism. Such a notion is maintained by the fact that the Fatimids usually appointed Sunnī figures in the state administrative body, including vizierate. ${ }^{72}$ Ibn Zulāq (d. 387/997) was able to make an account of the households and individuals who had turned into Shiism by his time; his father and grandfather were included. According to him some disclosed while others concealed their Shiism, which was chiefly represented in the high acclamation of 'Alī b. Abī Țâlib. ${ }^{73}$ The population of Cairo, in particular, remained largely Sunnī all through the Fatimid Caliphate. ${ }^{74}$ This would mean that the cenotaphs of the $\bar{A} l$ al-Bayt began to be consecrated in Egypt while the public funerary traditions were mainly Sunnī and not Shī $\overline{1}$ as many would think. That said, the Fatimids' use of the cenotaphs of the Âl al-Bayt did do the trick. ${ }^{75}$ It is true that it was not an effective tool for the conversion to Shiism, but it acted as a workable device in converging between the Fatimid 


\section{Celebrating the Dead in Ayyūbid Egypt: A Survey into Meaning and Architectural}

rulers and their Sunnī subjects; a matter for which the former were desperate (particularly in the aftermath of alMustansirir's notoriously detrimental famines).

As already referred to, some of the ashräf's tombs were real; that is they include underneath the corpses of those to whom they are attributed. Many were just memorials or cenotaphs (mashāhid ru'yā). A good example of the former is the above mashhad of Sayyida Nafĩsa. It is reported that when she passed in 208/823, her husband, Ishāq alMu'taman b. Ja'far al-Șādiq, contemplated on burying her in Madīna but the people of Egypt begged him to leave her cadaver in Egypt and so he did. ${ }^{76}$ She was buried in her house in Darb al-Sibā', a place where invocation is said to be accepted. The expression: 'mujarrab, 'tried and proven' is normally used by the narratives to confirm the place's precedence and prestige. According to al-Maqrīzī, the other three places where invocation is reportedly answered are: the place where Prophet Joseph was prisoned; the mosque of Moses at Țura; and the chamber on the left of the qibla of masjid al-Aqdām at the Qarāfa. ${ }^{77}$

Also, when al-Afḍal Shahanshah (d. 515 /1121), the famous vizier of caliph al-Musta 'lī billāh, was told about the merits of Zayd b. 'Alī Zayn al-'Ābidīn b. al-Husayn, he ordered that the debris of Zayd's mosque, having been burned in the late Fatimid time, should be cleared out. While so doing, he is said to have found the head of Zayd and so built a mashhad for it. Some folkloric tales were connected to this head, which was kept in the mosque of al-Afdal until the mashhad was built. ${ }^{78}$ It is also reported of al-Afdal to have visited the tomb of shaykh Abū Muhammad Abd al'Azīz b. Ja' far al-Khwārizmī (d. 401/1011), which was associated with many blissful features. ${ }^{79}$

After the decline of the Fatimid caliphate, the ashrāf continued to enjoy special deference. Abouseif argues that the Ayyūbids, while destroying the Fatimids' palaces, could not do the same with their shrines for they were venerated by both the Shiites and the Sunnites. ${ }^{80}$ In many cases, some dignitaries who lived under the Ayyūbids commended that they would love to be buried in the tomb of one of the Āl al-Bayt. The mashhad of Sukayna bt. alHusayn, for instance, included the bodies of two eminent figures: Ibrāhīm b. Yạ̣yā b. Balwa and Zaynab bt. Hasan b. Ibrāhīm b. Balwa (d. 646/1248); both were genealogists and descendants from 'Alī and Fātịma (sharīf nassāba). ${ }^{81}$ The high appreciation of the $\bar{A}$ l al-Bayt can be seen from the fact that their amity was itself deemed so virtuous that it brought good reputation. For example, the grave of Suhayl b. Ahmad, a member of the notorious Barmakīd dynasty, was considered with respect by Ibn 'Uthmān only for the former's appreciation to $\bar{A} l$ al-Bayt. ${ }^{82}$

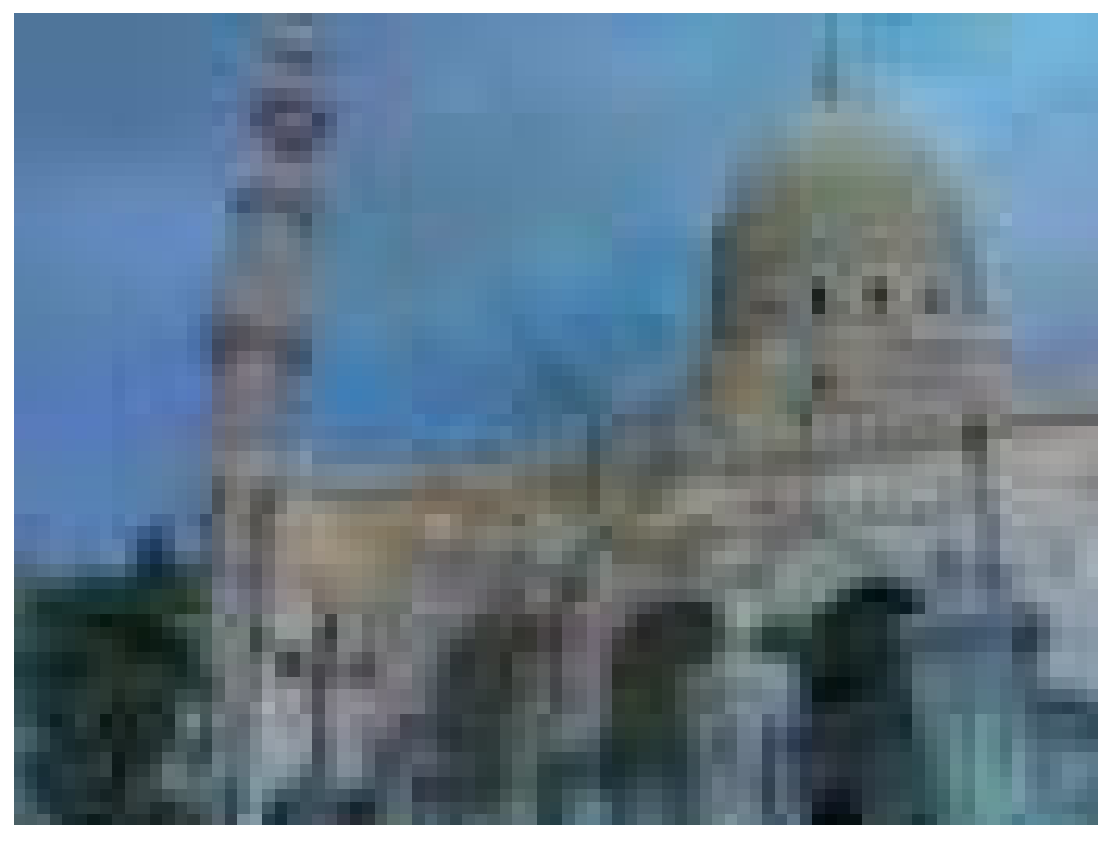

Pl. (10): Mashhad al-Sayyida Sukayna

(http://forums.egyptladies.net/t71601.html)

Sü fis

In the Ayyūbid period, however, many recognizable graves were attributed to sūfi figures (usually presented as al'ārifin billāh, 'those who truly know God'). For example, the renowned ascetic bard, 'Umar b. al-Fāriḍ (632/1235) was buried at the Qarāfa, near al-Muqaț̣am, just underneath the foot of his shaykh, Muhammad al-Baqqāl. A darīh was built on his grave since the Ayyūbid period. Another example is the grave of the șüfi shaykh Abū Ishāq Ibrahim (d. after 500/1107) which was included in the turba of al-Idfuwi $\overline{1}{ }^{83}$ It is attention-grabbing that quite a big number of the celebrated graves in the Fatimid period were for șüfi Sunnī figures. ${ }^{84}$ 
Some personages combined the two eminent features of being a sharîf and a șüfi. A famous example is Shaykh Abū al-Hajjāj al-Aqșurī, who died in 642/1245, that is in the sultanate of al-Ṣālih Najm al-Dīn Ayyūb. A tomb was founded for him at Luxor temple. ${ }^{85}$

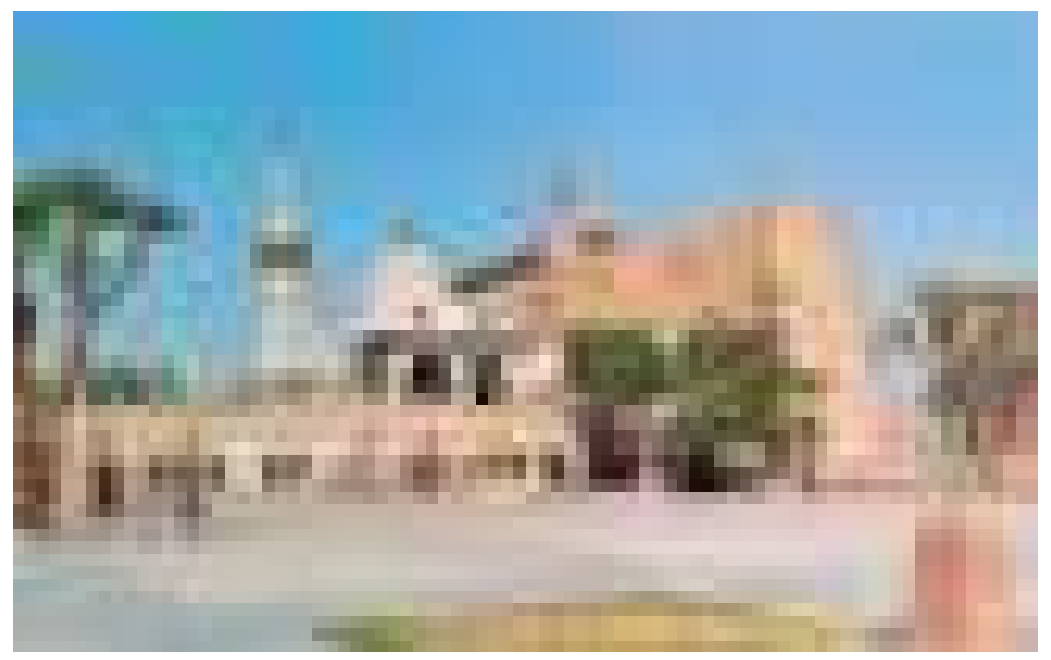

Pl. (11): Masjid and Ḍarīḥ of Abū al-Ḥajjāj al-Aqṣurī

(http://www.vetogate.com/480730)

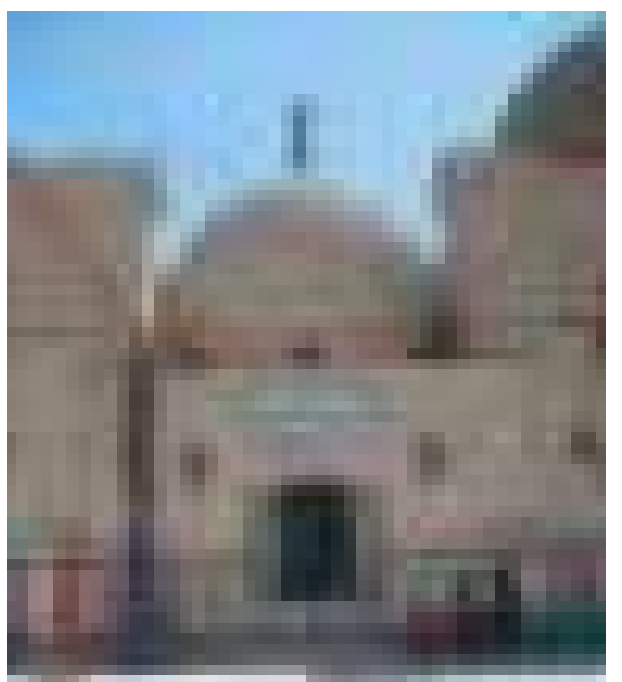

Pl. (12): Ḍarīḥ of 'Umar b. al-Fārị̣

(http://www.borsaat.com/vb/t320033.html)

\section{Ulema}

Under the Ayyūbids, the tombs of notable religious scholars also received public recognition. Nevertheless, the spiritual pre-eminence of scholars is, at least from the public point of view, not as certain as that of the ashräf or the șüfis. This is may be why the burial places of the former usually needed to be sanctified through the narrating some prodigies related to them. In the sources, such accounts are usually preceded by phrases like: yuqälu anna, 'it is said that', or taz 'umu-l 'àmmatu anna, 'the common people claim that'. ${ }^{86}$

Homage and tribute are said to have been paid to the tombs of early scholars even before the Ayyūbid established their sultanate. Al-Layth b. Sa'd, for instance, was buried at the gravesite of Șadaf, or al-Sadafiyyīn, which reportedly contained four hundred domes. ${ }^{87}$ Mainly drawing on al-Maqrīzī’s account on this gravesite, M. H. al-Haddād postulated that the tomb of al-Layth, just like the other four hundred tombs, was topped with a domed structure as early as the late second/eighth century. ${ }^{\mathbf{8 8}}$ Al-Maqrīzī, however, expressly agreed with the account of Muwaffaq b. 'Uthmān (author of Murshid al-Zuwwār) and that of Abū Muhammad 'Abd al-Karīm b. 'Abd Allāh (author of Hādī al-Rāghibīn fì Ziyārat Qubür al-Salihīn). ${ }^{89}$ According to these, it was not until 640/1242 that al-Layth's tomb was topped with the actual mashhad. Before that date, al-Layth's tomb took the form of a maștaba, 'bench'. The builder of the dome was Abū Zayd al-Mișrī, the most notable merchant of his time. ${ }^{90}$ Al-Layth's dome was seen by Ibn al-Jabbās, who stated 
that it was a blessed place where orison is said to be likely to be accepted. ${ }^{91}$ Due to its famed spiritual prestige, many of the eminent religious authorities (from the Ayyūbid period and before) loved to be buried in the vicinity of mashhad of al-Layth. One of these was Shibl al-Dawla al- Asqalānī, who died in 629/1232, as indicated by an inscription on the grave column. ${ }^{92}$

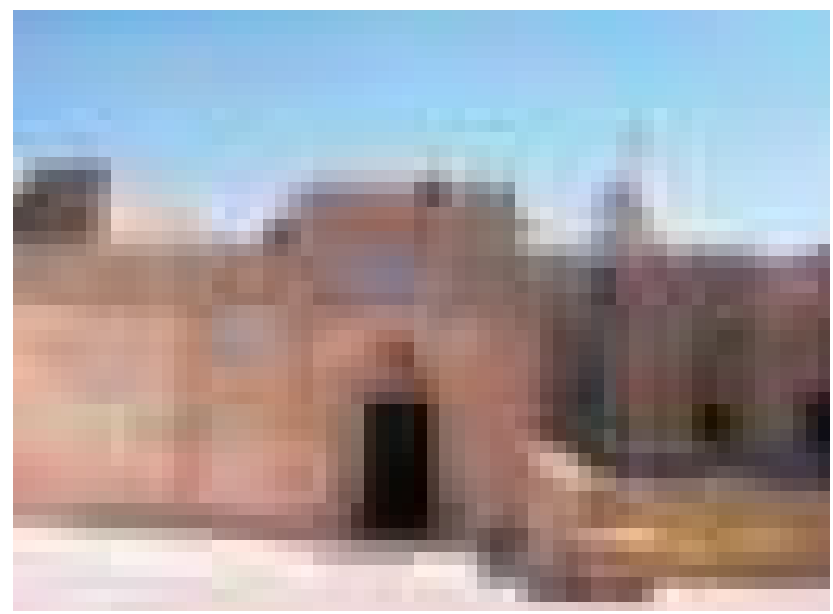

Pl. (14): Darīh of al-Layth b. Sa d

(http://www.msobieh.com/akhtaa/viewtopic.php?f=17\&t=12828)

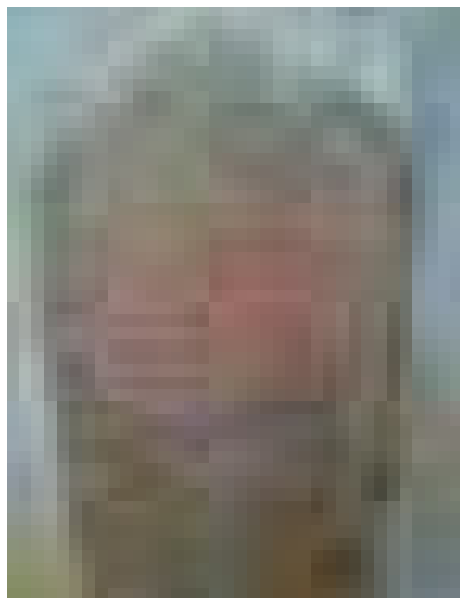

PI. (13): Gravestone of al-Layth b. Sa 'd

(http://www.msobieh.com/akhtaa/viewtopic.php?f=17\&t=12828)

Some of the prominent scholars who lived in Ayyūbid Egypt were later canonized, and thus their tombs received homage and deference from the public. In their life, they are said to have enjoyed respect from the Ayyūbid monarchs. For example, shaykh Abū al-Su' ūd b. Abī al- 'Ashā' ir (d. 644/1247), buried near to the cemetery of Ibn 'Ațā' al-Sakandarī at Muqaț̣am, was reportedly greatly respected by sultan al-Kāmil and his son and successor al-Ṣāliḥ Najm al-Dīn Ayyūb. ${ }^{93}$

Another model was Abū al-Ḥasan 'Alī b. 'Abd al-Raḥmān al-Mișrī al-Sakandarī (d. 550/1155), ${ }^{94}$ a remarkable muhaddith. It is said that the people of Egypt 'had much belief in him'. ${ }^{95}$ The same thing applies to shaykh Abū Bakr al-Idfuwī, a celebrated Qur' ān and hadīth scholar. ${ }^{96}$ This turba also includes the grave of a celebrated muqri', 'Qur'ān reciter', 'Abd al-Raḥmān b. 'Alī b. al-Husayn al-Anșārī (d. 603/1207). ${ }^{97}$ Other examples include: the tomb of the pious 'Abd Allāh al-Rūmī (d. 635/1238) at Qarāfat Quraysh;'98 the mashhad of Abū 'Abd al-Rahmān al-Diryāq (d. 558/1163), a hadīth scholar; ${ }^{99}$ and the tomb of Ibrāhīm b. Sa '̄id al-Habbāl, the most distinguished hadīth scholar of his time according to Ibn 'Uthmān. ${ }^{100}$

Some of the celebrated dead, however, combined the two imposing features of being a șüfi and a scholar. A good example is imām Muhammad b. Jābār al-Șūfì (d. 362/973) who is reported to have said: 'Sufism and ignorance do not coalesce'. ${ }^{101}$ It should also be noted that among the recognizable tombs in the Fatimid and the Ayyūbid periods, some belonged to reputed philologists such as Ibn Babshadh (d. 469/1077), ${ }^{102}$ while others were attributed to wellknown historians such as Abū Salāma 'Alī b. 'Abd Allāh al-Qựā'ī (d. 399/1009), the author of the Khițat who was buried at al-Shuqqa al-Kubrā, 'the Great Division'. ${ }^{103}$ 
Political figures

As already hinted, a number of the eminent political figures erected funerary domes for themselves or for members of their kin. In addition to the aforesaid examples of sultan Najm al-Dīn Ayyūb and his widow Shajar al-Durr (both erected by the latter), Abū Bakr al-Madhirrā'i (d. 283/896), the vizier of the Țulūnīds, built a grave for himself in a dome. ${ }^{104}$ The mausoleums of such political figures were usually abandoned unless they were associated with religious and spiritual standing. This may explain Ibn 'Uthmān's tendency to retail some anecdotes that would link the biography of Khumarawayh b. Ahmad b. Tulūn to the Necropolis and confer upon his mausoleum the needed prestige. ${ }^{105}$ Otherwise, for a tomb of a royalty or an official to be celebrated by the public, it should be patronized by some of his/her living associates. The greater the expenditure is, the bigger the number of the visitors is. The generous outlay put forth by emirs Jamāl al-Dīn 'Alī and 'Alā' al-Dīn b. Shāh was sufficient to make the turba of emir Tāj al-Mulūk b. Abī al-Hayjā (d. 590/1194) a real mecca for the Egyptian public, especially on feasts and religious occasions. ${ }^{106}$

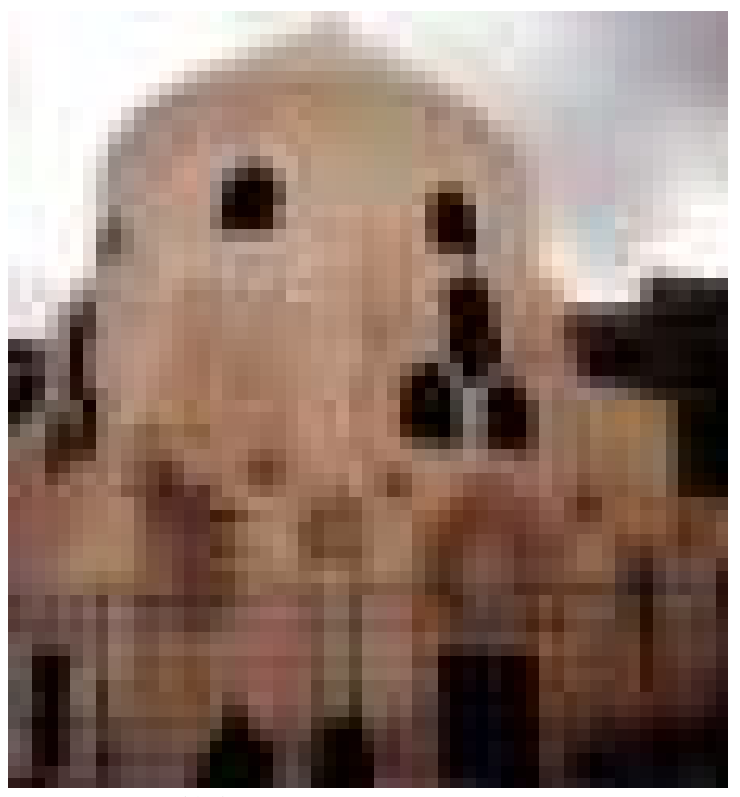

Pl. (15): Ḍarị̣̄ of Shajar al-Durr

(http://www.alasdeka2.com/vb/imgcache/139573.imgcache.jpg)

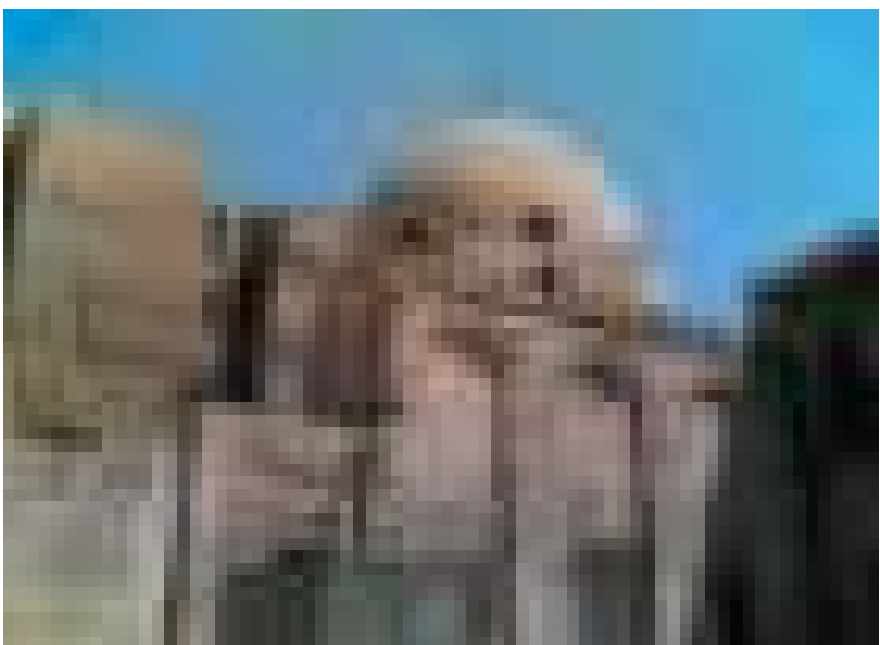

Pl. (16): Ḍarīḥ of Najm al-Dīn Ayyūb

(http://www.malekwktaba.com/?p=4227)

Meanwhile, some of those who held political positions, belonged to the ashräf class, and were hence acclaimed (more easily) by the populace of Ayyūbid Egypt. The mashhad of the Āl Tabātabā (datable ca. 334/943 according to Creswell), ${ }^{107}$ for instance, was known in the Ayyūbid period as a place where prayers are prospective to be fulfilled. This unique mausloean structure includes the graves of a number of the descendants of sharîf Abū Ishāq Ibrahim b. Ismail al-Dībājj, whose epithet was Țabāțabā. ${ }^{108}$ One of these was Țabāțabā's grandson, Ahmad b. Muhammad b. Ismail (d. 325/937). He is reported to have been a great helper for the destitute. When Ahmad b. Tulūn heard of the fact that Ahmad b. Ismail had nothing left for himself (after spending all his money as a charity), Ibn Țulūn 
granted him a village. ${ }^{109}$ The mashhad of Țabātabā also includes the body of the beneficent 'Abd Allah b. Ahmad d. Ismail (d. 348/959), a favourite of Abū al-Misk Kāfūr. It is of interest that 'Abd Allah was remembered by later people basically for his knowledge and wisdom as well as his spiritual status. ${ }^{110}$ Another well-known, and partly preserved, Ayyūbid mausoleum is that of al-Sādāt al-Tha'āliba. It was built by the sharīf, ${ }^{111}$ emīr Abū Nașr Ismā' $\bar{l}$ b. Hịșn alDawla Fakhr al-'Arab Tha 'lab who held the position of emir al-hạajj. ${ }^{112}$

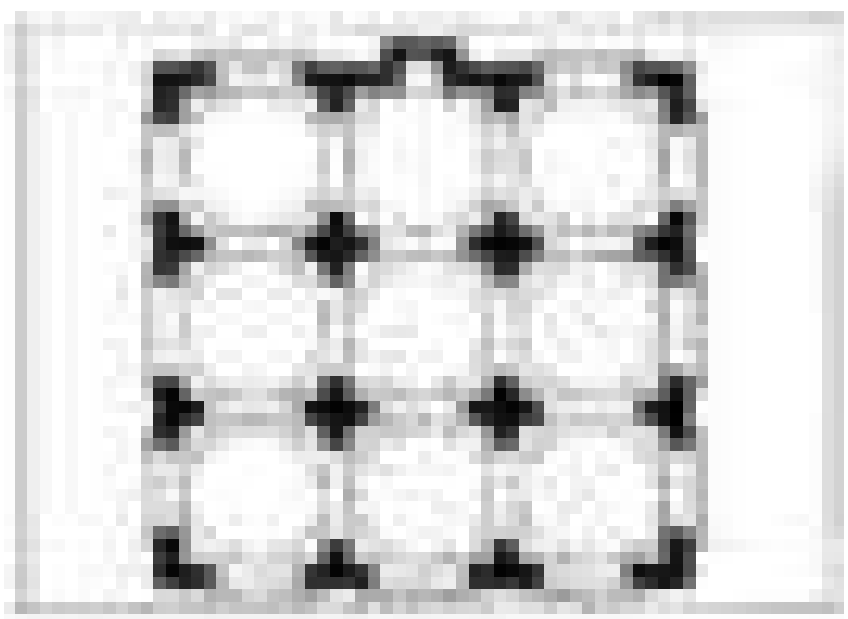

Fig. (3): Plan of Mashhad Ṭabāṭabā (Farīd Shāfi ‘̄̄, 1970)

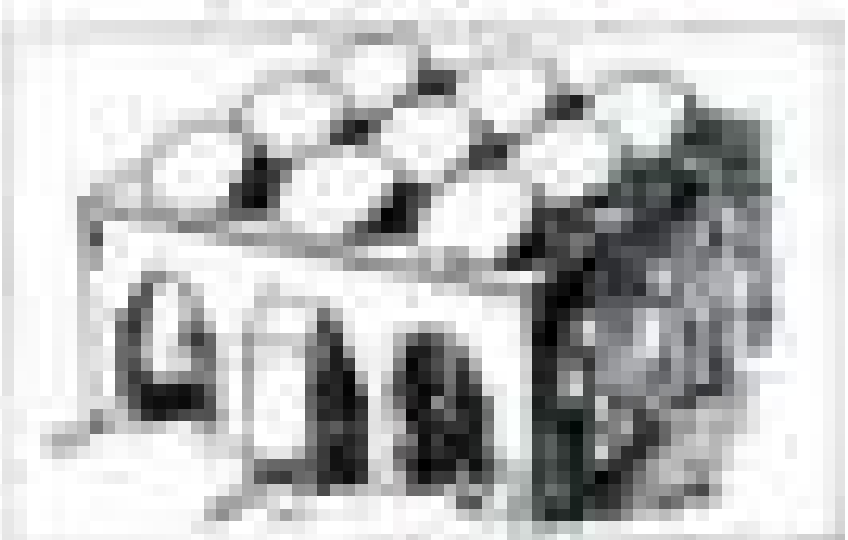

Fig. (4): Isometric plan of Mashhad Ṭabāṭabā (Farīd Shāfi ‘̄i, 1970)

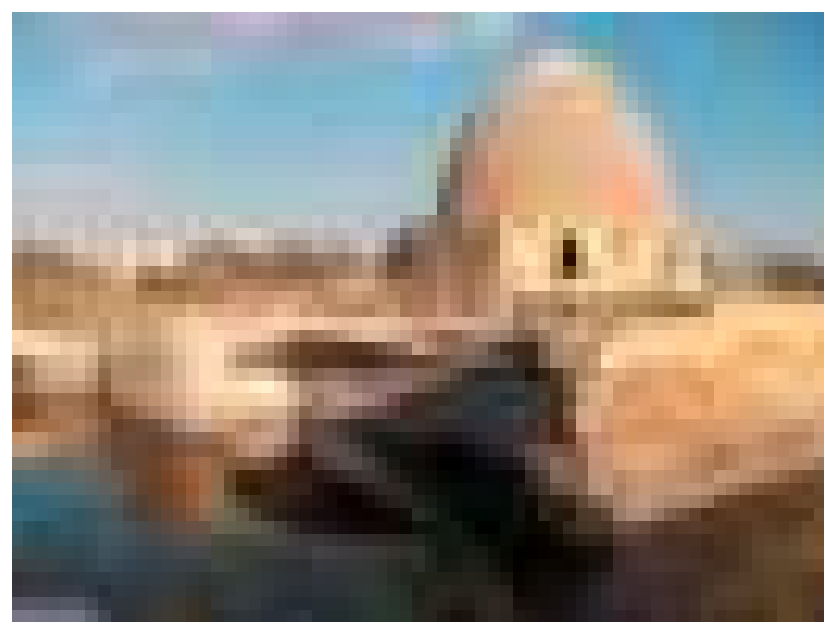

PI. (17): Remains of Mashhad Țabātabā

(http://www.archaeology.land/forums/viewtopic.php?t=33954) 


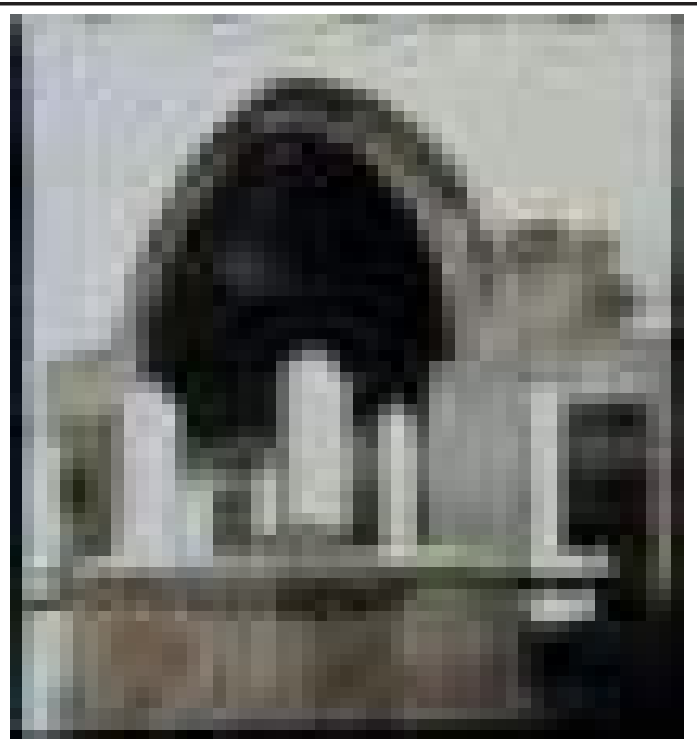

Pl. (18): Ḍarīḥ al-Sādāt al-Tha 'āliba (Creswell's Archive)

$Q \bar{a} d \bar{c} s$

The tombs of some of the notable $q \bar{a} d \bar{t} s$, 'chief judges', were also celebrated under the Ayyūbids. One of these was the tomb of imam Abū 'Abd Allāh b. Salāma b. Ja' far al-Quḍā' '̄ (d. 454/1062), the chief judge of Egypt and a favourite of the Fatimids. It is located at al-Shuqqa al-Kubrā. ${ }^{113}$ Also, according to some anecdotes, the tomb of qāḍ̄ Bakkār b. Qutyaba (d. 270/884) was known as a place where supplication is responded to. ${ }^{114}$

\section{The mausoleum of imām al-Shāfi î̀ as a model}

It is quite interesting to note that the grave, and not mausoleum, of Muhammad b. Idrīs al-Shāfi ' $\overline{1}$ was venerated-even by some of the Shiites-long time before the foundation of the Ayyūbid Dynasty. ${ }^{115}$ This, however strange it would seem, may be attributed to the reports putting al-Shāfi '⿳亠 in association with 'Alī b. Abī Țālib, albeit through dreams as usual. Al-Shāfi ' $\overline{1}$ is said, on the authority of al-Muzannī, to have dreamt of 'Alī b. Abī Țālib shaking hand with him, and putting his ring in al-Shāfí '̄'s finger. ${ }^{116}$ Abū al-Hasan al-Harawī (d. 611/1214) ${ }^{117}$ states that in his time al-Shāfi 's's mashhad was surrounded by a number of other (pre-existing) mashhads attributed to members of the $\bar{A} 1$ al-Bayt. ${ }^{118}$

Soon after his death in 204/820, al-Shāfi 'ī was buried at a turba, 'gravesite' owned by the offspring of Abī 'Abd Allāh b. al-Hakam, an eminent Egyptian Mālikī faqīh. ${ }^{119}$ According to Hasan 'Abd al-Wahāb, however, alShāfi' '̂'s grave (in spite of having been venerated by the mob) retained the form of a simple yard (săha) for more than three and a half centuries. ${ }^{120}$ This however, seems to be a misreading by Hasan 'Abd al-Wahāb of the sources. According to Ibn Iyās: '[...] and he [namely Șalāḥ al-Dīn] built the madrasa that is beside [the tomb of al-Shāfi' 1 ] . Formerly, it [namely the location of the madrasa] had been a $s \bar{a} h a^{\prime},{ }^{121}$

Most commentators believe that it was not until 572/1176 that the turba was built, allegedly for the first time, by Șalāh al-Dīn, who also built near to it a huge Shāfi ' $\overline{1}$ madrasa, called al-Ṣālihiyya. ${ }^{122}$ Indeed the grave of al-Shāfí ${ }^{\prime} \overline{1}$ seems to have been topped with a funerary structure even before the time of Șalāḥ al-Dīn. Al-Muqaddasī (d. 380/990), describing the tombs of the southern cemetery, states: 'their tombs are beautifully constructed; you [can easily] notice that a [populated] district is livid, while the tombs are white and stretching all along the region. In it (namely the cemetery) is the tomb of al-Shāfi ' $\overline{1}$ situated just between [those of] al-Muzann̄̄ and Abū Ishāa al-Marūzī' ${ }^{123}$ This implies that by the Fatimid period a funerary structure had risen over al-Shāfi 'î's grave.

What kind of a structure did Șalāh al-Dīn put up on al- Shāfí '̂̀'s grave? Was it a domed mausoleum? It is argued by some that a funerary dome had already been built over al-Shāfi '̄'s's grave by the Banū 'Abd al-Hakam, and that it was later renewed by Șalāh al-Dīn in 575/1179. ${ }^{124}$ Others suggest that Șalāh al-Dīn only built a madrasa, commissioned a wooden cenotaph, and undertook some restoration works-all done to rejuvenate Sunnism. ${ }^{125}$ Now, the only remaining part of Șalāh al-Dīn's construction is a wooden shrine with a pyramidal hood including the following inscription:

This blessed mausoleum (

'Abbās b. 'Uthmān b. Shāfi' b. al-Sā'ib [...], may God be merciful with him. It has been made by 'Ubayd alNajjār, known as Ibn Ma'ālī. He made it in 574 AH [...]. ${ }^{126}$

This foundation text clearly refers to a darīh. Nonetheless, the text, while ending with a plea of mercy for Ibn Ma'ālī and 'all the carpenters and painters who worked with him', ${ }^{127}$ makes no mention of builders. This may imply that 'darīh' refers here to the wooden cenotaph and not a funerary structure. Such an assumption, though, is challenged 


\section{Celebrating the Dead in Ayyūbid Egypt: A Survey into Meaning and Architectural}

by the fact that such a use of the term darịh is quite rare. The absence of any reference to builders or designers could well be ascribed to the fact that tribute is here paid to the makers of the wooden shrine specifically. Further, the contemporary chronicler, Ibn al-Athīr (630/1232-3), mentioning no architectural works made by Șalāḥ al-Dīn on the tomb of al-Shāfi ' $\overline{1}$, states that in 572/1177 Șalāḥ al-Dīn built the madrasa which is located atop al-Shāfi 'î's tomb. ${ }^{128}$

Luckily, we are helped in this discussion by the account of an eyewitness, the traveller Ibn Jubayr (d. 614/1217), who saw the work while in progress, particularly in the final stage. Describing the 'mashhad' of al Shāfi ' $\overline{1}$, Ibn Jubayr states: 'It is one of the most celebrated and spacious mashhads. [Just] across from it, a madrasa-of no peer in this country-has been built [...]'. ${ }^{129}$ Mainly drawing on this account of Ibn Jubayr, Mulder assumes that Șalāh alDīn built a mausoleum to commemorate the memory of al-Shāfí ' 1 who, by the Ayyūbid time, had been recognized as the greatest of all imams and the main campaigner of the Qur'ān and the Sunna. ${ }^{130}$ Such historical accounts are in all cases sufficient to deduce that Șalāh al-Dīn did build a mausoleum (most probably not a domed one) for al- Shāfí '⿳亠. But, was it intended to be a pilgrim object? Salāh al-Dīn's career, as a leading Sunni advocate, leaves us to think that he could not have patronized such a 'heretic' procedure for the grave of such a Sunni icon as al-Shāfi ' $\overline{1}$, who is over and above himself reported to have said: 'I deny it that a human should be exalted to the extent that his tomb is taken as a mosque, lest he or those who come afterwards should be led astray'. ${ }^{131}$

This being said, there is almost consensus in medieval and modern writings that it was not until 608/1211 that a funerary dome was constructed over the tomb of al-Shāfi ' 1 . And that was carried out by the Ayyūbid sultan alKāmil. ${ }^{132}$ Some went even further to argue that al-Kāmil's construction was intended to also serve, as a royal burial, on account of the fact that it included a cenotaph which al-Kāmil set aside for himself. The latter, however, died in Syria and was buried in Damascus. ${ }^{133}$ Against this background, we are told that when al-Khabushānī (Șalāḥ al-Dīn's religious reference) died in 587/1191, ${ }^{134}$ he was buried in the 'dome' just under the feet of al-Shāfi 's $1 .{ }^{135}$ The use of the word 'dome' here is a clear case of anachronism. It must be referring to the later dome of al-Kāmil. Al-Harawī observed that the mashahd of al-Shāfi 'ì also included the graves of 'Alī b. al-Ḥusayn b. 'Alī Zayn al-' Ābidīn, shaykh Abū 'Abd Allāh al-Kirānī and the Shāfí 'ì lineage of al-Hakam. ${ }^{136}$

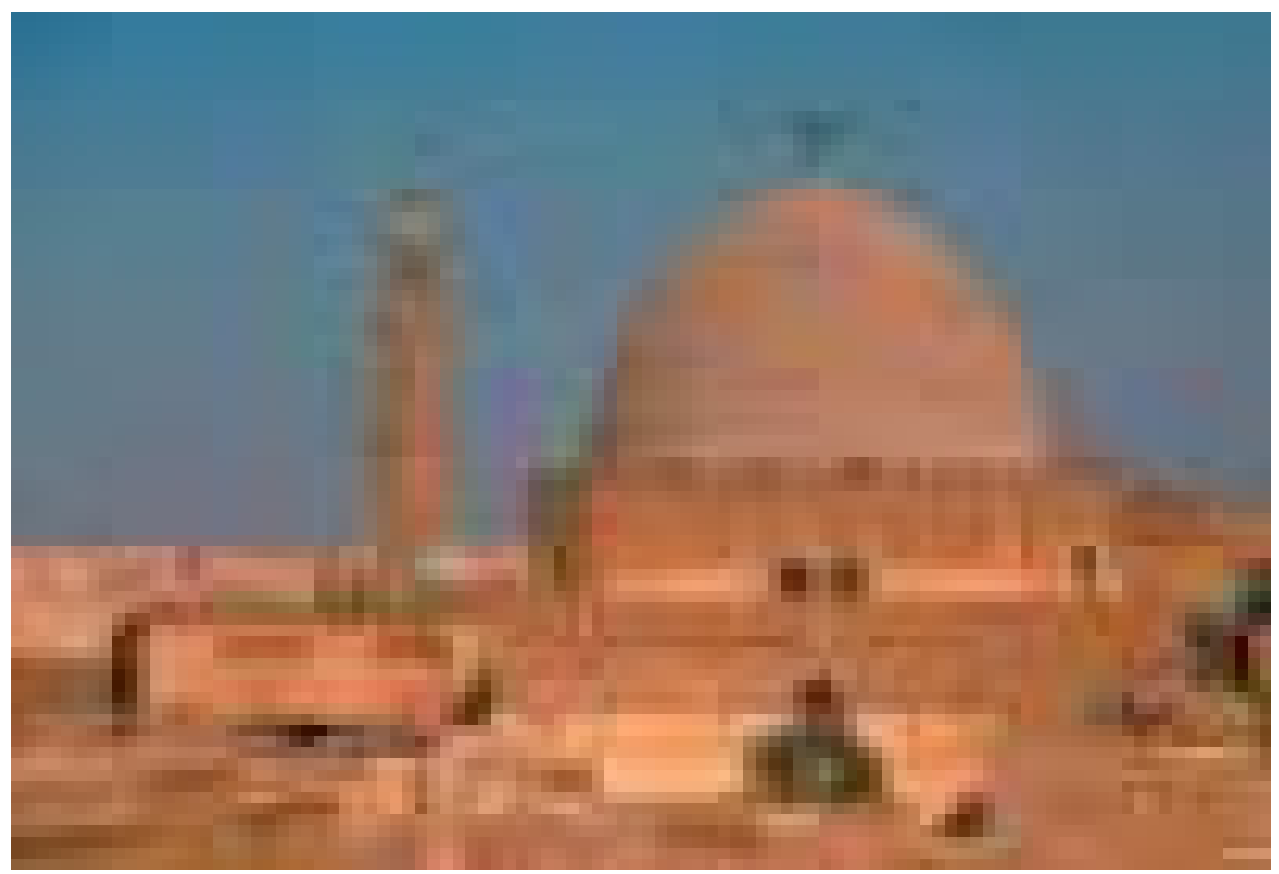

Pl. (20): Qubbat al-Shāfí 'ī (Richard Yeomans, 2006)

\section{Conclusion}

The major part of the tombs which were celebrated by the Egyptian populace under the Ayyūbids were founded in earlier Islamic epochs. Quite a big number of these were cenotaphs (honorary but not real ones), built by the Fatimids for members of the $\bar{A} l$ al-Bayt. The Ayyūbids inherited the monuments and with them the associated observances. Having noticed the positive role of such funerary structures in liaising between the Shī' $\overline{1}$ Fatimid rulers and their Sunn̄ Egyptian subjects, the Ayyūbids retained the same device of their previous political rivals. Since the time of the dynasty founder, Șalāḥ al-Dīn, mausolea began to be dedicated for a number of Sunnī religious figures such as al-Shāfi ‘ $\overline{1}$, who was widely admired by the Egyptians. Șalāh al-Dīn also built tombs for some of the Companions of the Prophet. If this was the formal trend of the Ayyūbid state, tombs for later members of the $\bar{A} l$ al-Bayt (ashrāf) continued to be erected-albeit by devoted well-to-does. Other mausolean structures that were celebrated by the Egyptians under the 
Ayyūbids belonged to Sufis, ulema, qāọ̄is, and political figures. Some mashhads were much older, attributed to early prophets and ancient historical figures.

For a deceased to be celebrated, he/she should have had a prominent biography that is preferably laced with piousness and spirituality. In some cases, these had to be combined with generous expenditure on the tomb and its visitors. Many of the attendants were attracted by the free food and beverage that were usually brought to such burial places. This survey has also found out that the sanctification of someone's biography and relics, including his burial place, usually needs quite some time. This mainly happened through the dissemination of reports on the feats and spiritual peculiarities of the departed and the blissful potentials of his/her burial place.

In the beginning, the celebrated tombs (just as many others) usually took the form of a chamber, bench or cairn. As early as the time of the Fatimids, the domed mausoleum has been the most dominant architectural expression of celebrated tombs in Islamic Egypt. Those attributed to religious authorities (including șahābīs, ashrāfe șūfìs and ulema) are usually referred to in the literature as mashhads, on account of them being visited by big masses of people. The mausolea of the secular and political figures, on the other hand, are typically referred to as madfan or darị. While 'darīh' can sometimes be used to denote the former group of burial places, mashhad are seldom used to refer to the latter group. It is quite rare, for instance, to find in the sources such expressions as 'the mashahd of al-Ṣālih Najm alDīn Ayyūb'.

It should, finally, be noted that the practice of celebrating the dead (particularly the pious ones) evolved under the Ayyūbids from a state-sponsored procedure into a public observation. This is quite evident from the vernacular style of building used for the majority of the Ayyūbid mausolea.

\section{Endnotes}

${ }^{1}$ Al-Tirmidhī, hadīth no. 1052. Abū Dāwūd, hadīth no. 3225; Ibn Māja, hadīths no. 1562-5. See also Abū Ya lā, hadīth no. 1020; al-Khațāōī, Ma 'ālim al-Sunan: Sharh 'Sunan al-Imām Ab̄̄ Dāwūd (d. AH 275)', ed. by M. Rāghib alṬabbākh, 4 vols (Aleppo: al-Maṭba ah al- 'Ilmiyyah, 1933), I, 319. Such hadīths are always found in Bāb al-Janā' iz, 'chapter of obsequies', in hadìth collections. See also Ibn al-Qayyim, Zād al-Ma 'àd fì Hadì Khayr al- 'Ibād, 27th edn, 6 vols (Beirut: Mu'asasat al-Risālah, 1991) I, 542. However, al-Tirmidhī reported that some early scholars like alHasan al-Bașrī (21/642-110/728) deem it $j \bar{a}^{\prime} i z$ to treat the graves with mud: hadìth no. 1052.

${ }^{2}$ See Ibn Taymiyya, Majmū 'al-Fatāwā, ed. by 'Āmir al-Jazzār and Anwar al-Bāzz, 3rd edn, 37 vols (Mansura: Dār alWafā', 2005), XXIV, 177-8; al-Mirdāwī, al-Inșāffì Ma 'rifat al-Rājih min-l-Khilāf 'alā Madhhab al-Imām alMubajjal Ahmad b. Hanbal, ed. by M. Hāmid al-Faq1̄, 12 vols ([n.p.]: King Su'ūd, 1956), II, 249-50.

${ }^{3}$ See Ibn Qudāma, Al-Mughnī, ed. by A. 'Abd al-Muḥsin al-Turkī and 'Abd al-Fattāḥ al-Hulw, 3rd rev. edn, 15 vols (Riyadh: dār 'Ālam al-Kitāb, 1997), II, 474. See also al-Qurțubī, Al-Jami lī Aḥkām al-Qur'ān: wal Mubayyin lima Taḍammanahū min-l-Sunnah wa Āy al-Furqān, ed. by A. 'Abd al-Muhsin al-Turkī, 24 vols (Beirut: Mu'sasat alRisālah, 2006), XXI, 261-5; Ibn Taymiyyah, Iqtị̣ā' al-Sirāṭ al-Mustaqīm li Mukhālafat Aṣhāb al-Jaḥim, ed. by Nāṣir al- 'Aql, 2 vols (Riyadh: Maktabat al-Rushd, [n.d.]), II, 679-80; Ibn Hajar, Fath al-Bārī bī Sharh al-Bukhārī, 14 vols (Cairo: Muștafā al-Halabī, 1959), II, 71; Ibn Rajab, Fath al-Bārī: Sharh Șaḥ̄ḥ al-Bukāhrī, ed. by M. S. 'Abd alMaqșūd, M. A. al-Shāfi ‘̂̀, I. I. al-Qāọ̄̄ and others, 910 vols (Medina: Maktabat al-Ghurabā’ al-Athariyya, 1996), III, 203-4.

${ }^{4}$ For the range of the hadìths of interdiction, see Mālik, hadìths no. 570-1; al-Bukhārī, hadìth no. 427; Muslim, hadìth no. 1183-4; Ibn Abī Shaybah, hadìth no. 7626, 7629; al-Dārimī, hadīth no. 1443; Ibn Hajar, Fath, II, P.78; Ibn Taymiyyah, Iqtid̄ā', I, 298-303; al-Hindī, Kanz, hadīths no. 19186-197. See also Muslim, hadìth no. 1188; Wensinck, p. 154. Al-Tirmidhī, hadīth no. 320; al-Baghawī, II, 417. Ibn 'Abd al-Barr al-Andalusī, Al-Tamhīd lima fil 'Muwatta' min-l-Ma 'ān̄̄ wa-l Asānīd, ed. by Muștafā al- 'Alawī and Muhammad al-Bakrī, 26 vols ([n.p.]: [n.pub.], 1967), V, 412. See also Thomas Leisten, 'Between Orthodoxy and Exegesis: Some Aspects of Attitudes in the Sharī'a toward Funerary Architecture', Muqarnas, 7 (1990), pp. 12-22.

5 Al-Bukhārī, hadīth no. 427; Muslim, hadīth no. 1183-4. Ibn Hajar argued that the images, mentioned by Umm Salama and Umm Ḥabība, were only mural drawings and not a relief, (lam yakun lahā zill, literally meaning 'had no shadow').

${ }^{6}$ Farīd Shāfi 'ī, Al- 'Imāra al- 'Arabiyya fì Mișr al-Islāmiyya: 'Așr al-Wulāh (Cairo: al-Hay'a al-Mișriyya al- 'Āmma lil Ta' liff wal Nashr, 1970), p. 256. The 'Abbāsids might have retained the Umayyad palaces because they deemed them as a great wealth, while mosques could not have been demolished because of their sanctity. Tombs, on the other hand, are closely related to whom they belonged to and thus their demolition would mean a lot.

${ }^{7}$ See F. Shāfi '̄', 'Imāra 'Arabiyya, p. 256. M. Hamza al-Ḥaddād, Al-Qibāb fi-l 'Imāra al-Mișriyya al-Islāmiyya (Cairo: Maktabat al-Thaqafa al-Dīniyya, 1993), p. 37.

${ }^{8}$ Al-Ṭabarī’s Tärīkh al-Rusul wa-l Mulūk, quoted by K.A.C. Creswell, The Muslim Architecture of Egypt, 2 vols. (Oxford: Oxford University Press, 1952-60), I, 110; Kamal al-Dīn Samih, 'Tațawwur al-Qubba fi-1 'Imāra alIslāmiyya;, Bulletin of the School of Arts, vol. 12, Issue 1 (1950), p. 7. This dome also includes the bodies of caliphs al-Mu'tazz and al-Muhtadī. 
${ }^{9}$ Oleg Grabar, 'The Earliest Islamic Commemorative Structures: Notes and Documents', Jerusalem, 4 (2005), pp. 65110 (p.73), first published in Ars Orientalis, 4 (1966), pp. 7-46. On the dome of Șulaybiyya, see also Alastair Northedge, The Historical Topography of Samarra, 2nd rev. edn, Samarra Studies, 1 (London: British School of Archaeology in Iraq, 2007).

${ }^{10}$ Grabar, 'Islamic Commemorative Structures', p. 75.

${ }^{11}$ J. Pedersen and others 'Masdjid', in The Encyclopaedia of Islam, 2nd edn, VI (1991), pp. 644-707 (651).

${ }^{12}$ Abū al-Ḥasan al-Shābashtī, Al-Diyārāt, ed. by Kurkis Awwad, 3rd edn. (Beirut: Dar al-Rā'id al- 'Arabī, 1986 ), p. 229.

${ }^{13}$ Zakariyya al-Qazwīn̄̄, Atthār al-Bilād wa-Akhbār 'Ibād (Beirut: Dār Șādir, [n.d.]), p. 392.

${ }^{14}$ See Șāliḥ Lam '̄i, Al-Turāth al-Mi 'mārī al-Islāmī fì Miṣr (Beirut: Dar al-Nahụa al- 'Arabiyya [?], 1975), p. 30. On this mashhad, see also Sayyida I. al-Kāshif, Miṣr fì 'Ahd al-Ikhshīdyyīn, p. 299; 'Abd al-Raḥmān Zakī, Mawsū 'at Madīnat al-Qāhira fì Alf 'Am (Cairo: 1969), p. 344; Aḥmad 'Abd al-Rāziq, Tārīkh wa-Āthār Miṣr al-Islāmiyya,(Cairo: Dar alFikr al-'Arabī, 1999), pp. 161-3.

${ }^{15}$ See Su'ād Māhir, Masājid Miṣr wa Awliyā uhā al-Șāliḥūn, 5 vols (Cairo: al-Majlis al-A 'lā lil Shu' ūn al-Islāmiyya, 1971), II, 11; Grabar, 'Islamic Commemorative Structures', pp. 22-3.

${ }^{16}$ Ibn Zulaq, Faḍā'l Miṣr wa-Akhbāruhā wa-Khawāṣṣuhā, ed. by 'Ali M. 'Umar (Cairo: Maktabat al-Khanjī, 1999), pp. 51-3.

${ }^{17}$ Ibn Zulaq, Faḍa'l 'Miṣr, p. 53.

${ }^{18}$ On the whole story, see al-Sakhāwī, Tuhfat al-Aḥbāb wa-Bughyat al-Ṭullāb: Fī al-Khitat wa-l Mazārāt wa-l Tarājim wa-l Biqāa' al-Mubārakāt, ed. by M. Rab̄̄i and H. Qāsim (Cairo: Maktabat al- 'Ulūm wa-1 Adāb, 1937), pp. 238-6; Ibn al-Zayyāt, Al-Kawākib al-Sayyāra fì Tartīb al-Ziyāra: F̄̄ al-Qarāfatayn al-Kubrā wa-l Sughrā (Cairo: al-Maṭba'a alAmīriyya, 1907), p. 110.

${ }^{19}$ Al-Sakhāwī, Tuḩfat al-Aḥbāb, p. 246.

${ }^{20}$ Muwaffaq al-Dīn b. 'Uthmān, Murshid al-Zuwwār Ilā Qubūr al-Abrār: al-Musammāa al-Durr al-Munazzam fì Ziyārat al-Jabal al-Muqațtam, ed. by M. Fatḥ̄ Abū Bakr (Cairo: al-Dār al-Miṣriyya al-Libnāniyya, 1995), pp. 282-3.

${ }^{21}$ An anonymous grave, for example, is said to have looked from distance as lit by a lamp (qindīl), which proved to be nothing if someone gets closer to it. Ibn 'Uthmān, Murshid al-Zuwwār, p. 327.

${ }^{22}$ Abū al-Hasan al-Harawī, Al-Ishārāt Ilā Ma 'rifat al-Ziyārāt, ed. by 'Alī 'Umar (Cairo: Maktabat al-Thaqāfa alDīniyya, 2002), p. 46.

${ }^{23}$ Al-Harawī, al-Ishārāt, p. 45.

${ }^{24}$ Al-Harawī, al-Ishārāt, pp. 46-7.

${ }^{25}$ See Ibn Manzūin, Lisān al- 'Arab, ed. by A. al-Kabīr, M. A. Ḥasab Allah, H. M. al-Shādhilī, rev, edn, 6 vols (Cairo: Dar al-Ma'ārif, 1981), IV, 2572.

${ }^{26}$ This $h \bar{u} s h$ includes a column marking the burial place of Tāj al-Dīn al-Bilyana' $\overline{1}$ (d. 603/1207), who was known as the servant of the Prophetic relics. See al-Sakhāwī, Tuhfat al-Aḥbāb, p. 227.

${ }^{27}$ The ḥush of al-Za farānī includes the tomb of the muhaddith, shaykh Ibn Wajīh (d. 444/1052). See al-Sakhāwī, Tuhfat al-Ahbāb, p. 245.

${ }^{28}$ See Ibn al-Zayyat, al-Kawākib al-Sayyāra, p. 110.

${ }^{29}$ Al-Sakhāwī, Tuhfat al-Aḥbāb, p. 240

${ }^{30}$ On the meaning and derivation of the word Qarāfa, see al-Maqrīzī who argued that the Egyptians had no other burial grounds: Al-Mawā 'iz wa-l I'tibār bi-Dhikr al-Khițț wa-l Āthār, ed. by M. Zeinhum and M. al-Sharqāwī, 3 vols (Cairo: Maktabat Madbūlī, 1998), III, 644-9. See also Christopher S. Taylor, In the Vicinity of the Righteous: Ziyāra and the Veneration of MuslimSaints in Late Medieval Egypt (Leiden: Brill, 1998), pp. 15-61.

${ }^{31}$ Al-Maqrīzī, al-Khițat, III, 643; 'Abd al-Raḥmān Zakī, Mawsū 'at al-Qāhira fì Ald 'Ām (Cairo: Maktabat al-Anglo, 1987), pp. 198-9, 281.

${ }^{32}$ On the merit of being buried at the Muqațam, see al-Maqrīzī, al-Khitat, III, $644 \mathrm{ff}$.

${ }^{33}$ Ibn Zulāq, Faḍ̄'l Miṣr P. 94; al-Harawi, al-Ishārāt, p. 38.

${ }^{34}$ Ibn Zulāq, Fậ̣a'l Miṣr, p. 95.

${ }^{35}$ Ibn Zulāq, Faụā'l Miṣr, p. 95-6; Ibn al-Zayyat, al-Kawākib al-Sayyāra, pp. 12-4.

${ }^{36}$ Ibn Zulāq, Faḍā'l Miṣr, p. 97.

${ }^{37}$ Al-Maqrīzī, al-Khitaț, III, 646. On the Masjid al-Qarāfa, see also III, 665.

${ }^{38}$ Mūsā b. Muhammad b. Sa'īd was the author of the Al-Mu arrab min Akhbār al-Maghreb.

${ }^{39}$ Al-Maqrīzī, al-Khitat, III, 646.

40 Ibid, III, 647.

${ }^{41}$ Al-Maqrīzī, al-Khitat, III, 646. See therein very interesting related poems.

${ }^{42}$ On this see, Christopher S. Taylor, 'Reevaluating the Shi ' 1 Role in the Development of Monumental Islamic Funerary Architecture: the Case of Egypt', Muqarnas, vol 9 (1992), pp. 1-10 (p. 8).

${ }^{43} \mathrm{Su}$ 'ād Māhir, Masājid Mișr, II, 186.

${ }^{44}$ Ibid, II, 213.

${ }^{45}$ Al-Maqrizi, al-Khițat, III, 212-. On the Fatimids' celebration of the Day of 'Āshūrā', see Ibn al-Ṭuwayer, Nuzhat alMuqlatayn fì Akhbar al-Dawlatyn, ed. by Ayman Fu'ād Sayyid, (Stuttgart: Franz Steiner, 1992), pp. 223-4. 
${ }^{46}$ Maqrīzī, al-Khițaț, III, 689. Al-Maqrīzī also mentions that some used to visit on Saturday. See also Ibn al-Zayyāt, alKawākib al-Sayyāra, p. 30.

${ }^{47}$ Al-Maqrīzī, al-Khitaț, III, 689.

${ }^{48} \mathrm{Su}$ 'ād Māhir, Masājid Miṣr, II, 212.

${ }^{49}$ Ibid, II, 229.

${ }^{50}$ Ibid, II, 261; Doris Behrens-Abouseif, Islamic Architecture in Cairo: An Introduction (Leiden: Brill, 1989), pp. 91-3; Richard Yeomans, The Art and Architecture of Islamic Cairo (Reading: Garnet, 2006), p. 121.

${ }^{51}$ Ibn 'Uthmān, Murshid al-Zuwwār, p. 372. on Zahrūn, see p. 277.

52 Al-Sakhāwī, Tuhfat al-Aḥbāb, p. 80; Su'ād Māhir, Masājid Miṣr, II, 236.

${ }^{53}$ Al-Sakhāwī, Tuhfat al-Aḥbāb, p. 80; Behrens-Abouseif, Islamic Architecture in Cairo, pp. 90-1.

${ }^{54}$ Ibid, p. 281.

${ }^{55}$ Al-Sakhāwī, Tuhfat al-Aḥbāb, p. 263. On the turba of Abū al-Fadl b. al-Jawhari, see p. 261.

${ }^{56}$ See Ibn 'Uthmān, Murshid al-Zuwwār, pp. 297-303. When Badr al-Jamālī, the famous vizier of the Fatimids and the commander-in-chief, heard of Abū al-Faḍl's efforts to defend Sunnism, he ordered that the latter should be brought, albeit forcefully, to Egypt. Nevertheless, a miracle is said to have protected the pious man from al-Jamālî's punitive measures. Abū al-Faḍl, then, returned to Egypt where he continued to disseminate the Sunnī rite. However, he was summoned again: this time by the Fatimid caliph himself after knowing about Abū al-Faḍl's campaign to rejuvenate Sunnism. But he managed to weather the caliph's wrath, along with that of Badr al-Jamālī on a later occasion, thanks to his prowess in poetry. He was then left to preach as he liked. See Ibn 'Uthmān, Murshid al-Zuwwār, pp. $299-301$.

${ }^{57}$ See Ibn Uthman, Murshid al-Zuwwār, p. 210.

${ }^{58}$ As an example, see Ibn 'Uthmān, Murshid al-Zuwwār, pp. 309-10, 319.

${ }^{59}$ For some of the karamāt, 'miracles' of the pious and how they formulated and disseminated, see Yūsuf al-Nabhānī, Jāmi 'Karāmāt al-Awliyā', ed. by Ibrahim A. 'Awaḍ, 2 vols (Gujrat: Markaz-e-Ahl-e-Sunnat Barkat-e-Raza, 2001).

${ }^{60}$ Al-Harawī, al-Ishārāt, pp. 40, 42.

${ }^{61}$ Ibid, p. 38.

${ }^{62}$ A standard weight scale that measures 2.6 kilograms (ca. 2512 millilitres)

${ }^{63} \mathrm{Al}-\mathrm{Haraw} \overline{\mathbf{1}}$, al-Ishärāt, p. 38. The $s \bar{a}^{\text {' }}$ is a measuring unit equivalent to 3 kilograms.

${ }^{64}$ Ibid, pp. 39, 42-4.

${ }^{65}$ Ibn Zulāq, Faḍā'l Miṣr, p. 53.

${ }^{66}$ Al-Harawī, al-Ishārāt, p. 37.

${ }^{67}$ Al-Sakhāwī, Tuhfat al-Aḥbāb, p. 101.

${ }^{68}$ See Ibn al-Zayyāt, Al-Kawākib al-Sayyāra, pp. 41-2; 'Uqba was made the ruler of Egypt by Mu'āwiya b. Abī Sufyān.

${ }^{69}$ Al-Sakhāwī, Tuhfat al-Ahbāb, p. 345. On the qabr of 'Uqba b. 'Āmir see Ibn 'Uthman, Murshid al-Zuwwār, p. 146-7.

${ }^{70}$ Al-Maqrīzī, al-Khitat, III, 526; al-Sakhāwī, Tuhfat al-Aḥbāb, p. 143.

${ }^{71}$ See al-Maqrīzī, al-Khițț, III, 640-1; al-Sakhāwī, Tuhfat al-Aḥbāb, p. 129, 134-5. See also Ibn al-Zayyāt, al-Kawākib al-Sayyāra, pp. 34-5. Caroline Williams, 'the Cult of 'Alid Saints in the Fatimid Monuments of Cairo Part II: The Mausolea', Muqarnas vol. 3 (1985), pp. 39-60 (pp. 47-8); Grabar, 'Earliest Islamic Commemorative', p. 29. On those figures who visited the tomb of Sayyida Nafĩsa, see Ibn 'Uthman, Murshid al-Zuwwār, pp. 179-81.

${ }^{72}$ See Michael Chamberlain, 'The Crusader Era and the Ayyūbid Dynasty', in The Cambridge History of Egypt, Volume 1, p. 214. See also Devin J, Stewart, 'Popular Shiism in Medieval Egypt: Vestiges of Islamic Sectarian Polemics in Egyptian Arabic', pp. 35-66.

${ }^{73}$ Ibn Zulāq, Faḍ̄'l Mișr, pp. 48-9.

${ }^{74}$ Chamberlain, 'The Crusader Era and the Ayyūbid Dynasty', p. 216, 232.

${ }^{75}$ See Taylor, 'Shi ' 1 Role in the Development of Monumental Islamic Funerary Architecture', pp. 1-10.

${ }^{76}$ Al-Sakhāwī, Tuhfat al-Aḥbāb, p. 128; Caroline Williams, 'The Cult of Alid Saints', pp. 39-40. It is said that her spouse did not agree to leave her body in Egypt until he dreamed of the Prophet asking him to do so.

77 Al-Maqrīzī, al-Khițt, III, 640. See also al-Sakhāwī, Tuhfat al-Aḥbāb, p. 129, 134-5.

${ }^{78}$ Al-Sakhāwī, Tuhfat al-Aḥbāb, pp. 143-4.

${ }^{79}$ Ibn 'Uthmān, Murshid al-Zuwwār, p. 327; al-Sakhāwī, Tuhfat al-Aḥbāb, p. 255.

${ }^{80}$ Behrens-Abouseif, Islamic Architecture in Cairo, p. 85.

${ }^{81}$ Al-Sakhāwī, Tuhfat al-Ahbā̄b, pp. 115-; Ibn al-Zayyāt, al-Kawākib al-Sayyāra, pp. 30-1 .

${ }^{82}$ Ibn 'Uthmān, Murshid al-Zuwwār, p. 233-4. Suhayl b. Aḥmad was a script of Egypt's kharājj.

${ }^{83}$ Al-Sakhāwī, Tuhfat al-Ahbā̄b, p. 277.

${ }^{84} \mathrm{See}$, as an example, Ibn 'Uthmān, Murshid al-Zuwwār, pp. 304-27

${ }^{85} \mathrm{Su}$ 'ād Māhir, Masājid Miṣr, II, 241.

${ }^{86}$ Al-Sakhāwī mentions it more than once in one page: Tuhfat al-Ahbāab, p. 157.

${ }^{87}$ Al-Maqrīzī, al-Khițtat, III, 695; Su'ād Māhir, Masājid Miṣr, II, 221. See also Ibn al-Zayyāt, al-Kawākib al-Sayyāra, pp. 102-4.

${ }^{88}$ M. Hamza al-Haddād, al-Qibāb, pp. 41-2.

${ }^{89}$ See al-Maqrīzī, al-Khițat, III, 695. The same opinion is also held by Ibn al-Zayyāt: al-Kawākib al-Sayyāra, p. 101. 
${ }^{90}$ Al-Maqrīzī, al-Khițat, III, 695; Su'ād Māhir, Masājid Miṣr, II, 221.

${ }^{91}$ Ibn al-Zayyāt, al-Kawākib al-Sayyāra, p. 101; Su'ād Māhir, Masājid Miṣr, II, 220.

${ }^{92}$ Al-Sakhāwī, Tuhfat al-Aḥbāb, p. 230.

${ }^{93}$ See Ibn al-Zayyat, al-Kawākib al-Sayyāra, pp. 316-19; Su'ād Māhir, Masājid Mișr, II, 245.

${ }^{94} \mathrm{He}$ was known as Ibn al-Jassās.

${ }^{95}$ Al-Sakhāwī, Tuḥfat al-Aḥbāb, p. 153.

${ }^{96}$ Ibn 'Uthmān, Murshid al-Zuwwār, pp. 271. The turba of al-Idfuwī includes the graves of some celebrated șahāāis and $t a b i$ ' $i s$. Of them, many were traditionists. The majority of them had passed in the second/eighth century.

${ }^{97}$ Al-Sakhāwī, Tuḥfat al-Aḥbāb, pp. 167-9.

${ }^{98}$ Ibid, pp. 206-7.

${ }^{99}$ Ibid, p. 328.

${ }^{100}$ Ibn 'Uthmān, Murshid al-Zuwwār, p. 277.

${ }^{101}$ Al-Sakhāwī, Tuhfat al-Aḥbāb, p. 256.

${ }^{102}$ Ibn 'Uthmān, Murshid al-Zuwwār, p. 283.

${ }^{103}$ Al-Sakhāwī, Tuḥfat al-Aḥbāb, pp. 245-6.

${ }^{104}$ Ibn 'Uthmān, Murshid al-Zuwwār, p. 265; Ibn al-Zayyat, al-Kawākib al-Sayyāra, p. 73-4.

${ }^{105}$ Ibn 'Uthmān, Murshid al-Zuwwār, p. 263-4.

106 Al-Sakhāwī, Tuḥfat al-Aḥbāb, p. 178.

${ }^{107}$ Creswell dates this mashhad to the year of the death of Țabātabā al-Asghar, the brother of 'Abd Allāh b. Ahmad: Muslim Architecture of Egypt, I, 11-5.

${ }^{108}$ See Ibn al-Zayyāt, Al-Kawākib al-Sayyāra, pp. 59-64; Oleg Grabar, 'The Islamic Commemorative Structures', p. 11. Țabātabā himself is said have died outside Egypt.

${ }^{109}$ See Ibn 'Uthmān, Murshid al-Zuwwār, p. 237.

${ }^{110}$ See Ibn 'Uthmān, Murshid al-Zuwwār, pp. 235- (especially 246-7). The mashahd of Āl Ṭabāṭabā also includes the grave of Ibn Zulāq, the famous historian. See Ibn 'Uthmān, Murshid al-Zuwwār, p. 256.

${ }^{111}$ Sharīf is a descendant of the Prophet through his daughter Fatima and Cousin 'Alī b. Abī Ṭālib.

${ }^{112}$ Su'ād Māhir, Masājid Miṣr, II, 192-98. On the mashhad al-Sadat al-Tha'āliba, see al-Sakhāwī, Tuḥfat al-Aḥbāb, p. 326.

113 Al-Sakhāwī, Tuhfat al-Aḥbāb, p. 245.

${ }^{114}$ Ibn 'Uthmān, Murshid al-Zuwwār, p. 228. Bakkār was first buried near the old muṣallā of Banū Miskīn. See Ibn 'Uthmān, Murshid al-Zuwwār, pp. 214-29.

115 See Stephennie Mulder, 'The Mausoleum of Imām al-Shāfi '̄̄’, Muqarnas, vol. 23 (2006), pp. 15-46 (p. 20).

${ }^{116}$ Ibn Uthman, Murshid al-Zuwwār, p. 483.

${ }_{117}$ Al-Harawī, al-Ishārāt, pp. 38-9.

118 Al-Harawī, al-Ishārāt, p. 39. For the names of the owners of these mashhads, see al-Harawī, al-Ishārāt, p. 39.

${ }^{119}$ See Ibn 'Uthmān, Murshid al-Zuwwār, p. 495; Hasan 'Abd al-Wahab, Tārihk al-Masājid al-Athariyya fi-l Qāhira, 2 vols, 2nd edn (Beirut: Awraq Sharqiyya, 1993), I, 106; E. Chaumont, 'Al-Shāfi '̀̀', in The Encyclopedia of Islam, IX, 183. This turba was also known as Banū Zuhra. See al-Maqrīzī, al-Khițat, III, 692.

${ }^{120}$ Hasan 'Abd al-Wahāb, Tārihk al-Masājid al-Athariyya, I, 107.

${ }^{121}$ Ibn Iyās, Badā 'i 'al-Zuhūr fì Waqā' 'i al-Duhūr, 3 vols (Cairo: Matābi' al-Sha 'b, 1960), I, 58.

${ }^{122}$ Ibn Taghrī Bardī, Al-Nujūm al-Zāhira fi Mulūk Mișr wa-l Qāhira (Beirut: Dār al-Kutub al- 'Ilmiyya, 1992), VI, 51, 72; Hasan 'Abd al-Wahāb, Tārihk al-Masājid al-Athariyya , I, 107.

${ }^{123}$ Al-Muqaddasī, Aḥsan al-Taqāsīm fī Ma rifat al-Aqālīm (Leiden: Brill, 1877), p. 209.

${ }^{124}$ See Su'ād Māhir, Masājid Miṣr, II, 149. On the mausoleum of imam al-Shāfi '̀̃, see al-Sakhāwī, Tuhfat al-Aḥbāb, pp. $320 \mathrm{ff}$.

${ }^{125}$ See Behrens-Abouseif, Islamic Architecture in Cairo, pp. 85-v; Richard Yeomans, The Art and Architecture of Islamic Cairo, pp. 111-2.

${ }^{126}$ See Su'ād Māhir, Masājid Miṣr, II, 150-1. See also Behrens-Abouseif, Islamic Architecture in Cairo, p. 87.

${ }^{127}$ Hasan 'Abd al-Wahab, Tārihk al-Masājid al-Athariyya, I, 108.

${ }^{128}$ Ibn al-Athīr, al-Kāmil, X, 84.

${ }^{129}$ Ibn Jubayr, Al-Rihla (Beirut: Dār Șādir lil Țibā'a wal Nashr, [1964 (?)]), p. 22. On this madrasa see al-Suyūṭ̄, Hush al-Muḥậ̣ara fì Tārīkh Miṣr wa-l Qāhira, ed. by M. Abū al-Faḍl Ibrāhīm, 2 vols (Cairo: 'Īsā al-Halab̄i, 1967), II, 257; Kamāl al-Dīn Sāmiḥ, Al- 'Imāra al-Islāmiyya fì Miṣr (Cairo: Maktabat al-Nahụa al-Mișriyya, [n.d]), p. 76.

${ }^{130}$ On the standing of al-Shāfi ' $\overline{1}$, see for example, Ibn 'Uthmān, Murshid al-Zuwwār, pp. 483-95.

131 Al-Maqrīzī, al-Khițt, III, 643. On how a grave should look like according to sunna, see Ibn 'Uthman, Murshid alZuwwār, pp. 64-7. The ardent Sunni historian and faqīh, al-Suyūṭị, for instance, describes Șalāḥ al-Dīn as the most beneficent monarch in the history of Islam: Husn al-Muhāọara, II, 257.

${ }^{132}$ See Ibn al-Zayyāt, Al-Kawākib al-Sayyāra, p. 212; al-Maqrīzī, al-Khițtạ, III, 694.

${ }^{133}$ Yeomans, The Art and Architecture of Islamic Cairo, p. 115. 
${ }^{134}$ Al-Khabushānī was the greatest sunnī figure in the time of Șalāh al-Dīn. He came to Egypt in 565/1170 and stayed at the turba of al-Shāfi 'ī. Then, Șalāḥ al-Dīn entrusted him with funds to build a madrasa for the Shāfi 'ītes. See Su ād Māhir, Masājid Mișr, II, 176

${ }^{135}$ Su àād Māhir, Masājid Miṣr, II, 176-7; Șalāḥ al-Dīn al-Șafadi, Al-Wāfì bil Wafāyāt (Beirut: Dar Ihyyā' al-Turāth, 2000), VI, 68. On the mausoleum of imam al-Khabushānī, see al-Sakhāwī, Tuḥfat al-Aḥbāb, p. 325.

${ }^{136}$ Al-Harawī, al-Ishārāt, p. 39.

\section{الإحتفاء بالموتى في مصر الأيوبية: بحثٌ في الإِلالة والمظهر المعماري}

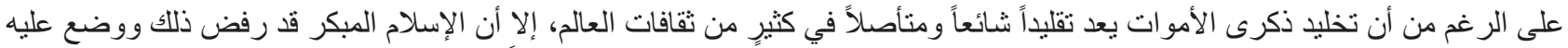

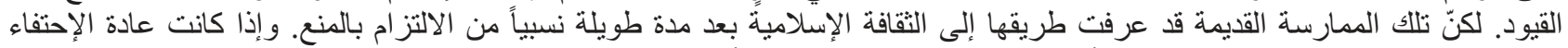

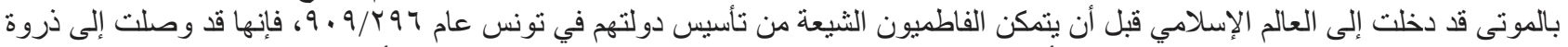

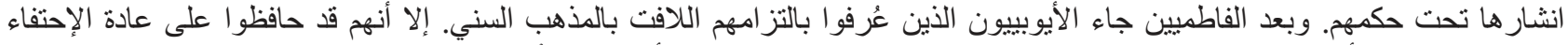

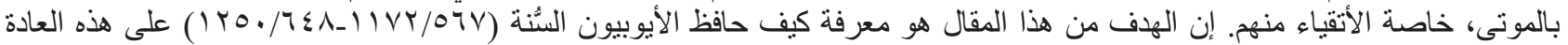

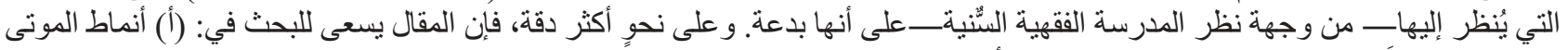

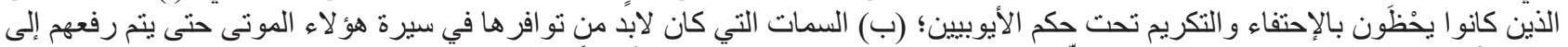

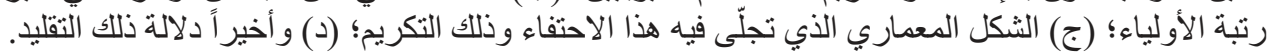

